\title{
Late-Variscan emplacement and genesis of the Vieira do Minho composite pluton, Central Iberian Zone: Constraints from U-Pb zircon geochronology, AMS data and $\mathrm{Sr}-\mathrm{Nd}-\mathrm{O}$ isotope geochemistry
}

\author{
Helena C.B. Martins *, Helena Sant'Ovaia, Fernando Noronha \\ Geology Centre/Department of Geosciences, Environment and Spatial Planning, Faculty of Sciences, Porto University, Rua do Campo Alegre 4169-007 Porto, Portugal
}

\section{A R T I C L E I N F O}

\section{Article history:}

Received 7 March 2012

Accepted 3 January 2013

Available online 12 January 2013

\section{Keywords:}

Peraluminous granites

Iberian Variscan Belt

AMS

$\mathrm{Sr}-\mathrm{Nd}-\mathrm{O}$ isotopes

\begin{abstract}
A B S T R A C T
In the Central Iberian Zone synorogenic (syn- and late- $\mathrm{D}_{3}$, the last deformation phase) composite batholiths of biotite-rich granitods with peraluminous character are well represented. We report here $\mathrm{U}-\mathrm{Pb}$ zircon and monazite ages, geochemical, Sr-Nd-O isotopic data and Anisotropy of Magnetic Susceptibility (AMS) studies for the late- $\mathrm{D}_{3}$ Vieira do Minho pluton, in northern Portugal. AMS reveals the paramagnetic behaviour of these granites and the magnetic fabric enhances the major role of NW-SE regional anisotropies on controlling the ascent and emplacement of the magmas. Magnetic anisotropy and medium temperature microstructures also point out the evolution of regional tectonics during crystallization of the magma. U-Pb zircon and monazite analyses yield consistent ages of $310 \pm 2 \mathrm{Ma}$ and $312 \pm 2 \mathrm{Ma}$, interpreted as emplacement age. The Vieira do Minho pluton consists of two peraluminous monzogranites, the VMG and the MRG. Both have similar $\varepsilon_{\mathrm{Nd}}$ values $\left(\mathrm{VMG}=-5.2\right.$ to $-5.7 ; \mathrm{MRG}=-4.98$ to -5.96 ) but the VMG is slightly enriched in ${ }^{87} \mathrm{Sr} /{ }^{86}{ }_{\mathrm{i}}=$ $0.7087-0.7098$ as well as in $\delta^{18} \mathrm{O}$ in the range of $10.6 \%$ to $11.0 \%$ o than the MRG with ${ }^{87} \mathrm{Sr} /{ }^{86}{ }_{\mathrm{i}}=0.7064-0.7075$ and $\delta^{18} \mathrm{O}=9.9 \%$-10.5\%. These granites are associated with coeval scarce grabroic intrusions and/or mafic microgranular enclaves which are not considered as mafic precursors of the associated granitic magmatism. Instead, a lower metaigneous crustal source, at different levels, is proposed based on the available data set.
\end{abstract}

(c) 2013 Elsevier B.V. All rights reserved.

\section{Introduction}

The generation and emplacement of granitoids, which are well represented in orogenic belts, are fundamental processes of continental recycling and/or crustal growth. Although controversial, the type and nature of the processes responsible for the genesis of different granitic magmas can involve partial melting of distinct source rock materials, hybridisation of magmas with contrasting compositions, fractional crystallization, crustal contamination and more complex models, such as assimilation-fractional crystallization process (Bea et al., 1999; Bonin, 2004; Castro et al., 1999; Collins et al., 2000; Dias and Leterrier, 1994; Dias et al., 2002; Janousek et al., 2004; Moreno-Ventas et al., 1995; Patiño-Douce, 1999; Renna et al., 2006; Silva and Neiva, 2004; Slaby and Martin, 2008; Villaseca et al., 1998, 2008, 2009). Thus, their study offers an important contribute to a better knowledge of the mechanisms of magma genesis and the deep continental crust evolution, giving together insights about the nature of source rocks that are melted.

Moreover, granitoids are useful indicators of crustal kinematics allowing a reconstruction of the late stages of the tectonic evolution of orogenic belts (Gleizes et al., 1997). Development and interpretation of fabric patterns during the different stages of emplacement or during

\footnotetext{
* Corresponding author. Tel.: + 351 220402461; fax: + 351220402490.

E-mail address: hbrites@fc.up.pt (H.C.B. Martins).
}

regional post-emplacement deformation of granitic bodies can be of critical importance. The Anisotropy of Magnetic Susceptibility (AMS) is a powerful tool to investigate the internal structures of plutons where the macroscopic preferred mineral orientation is poorly expressed or absent (e.g. Bouchez, 1997). In particular, the lineation is often difficult to obtain from field studies alone because granitoids do not develop planar and linear fabrics that can be easily observed, unless they are significantly deformed, except microgranular, feldspar megacryst bearing, granitoids and schlieren rich granites.

The Late Variscan Vieira do Minho composite granite pluton offers a good opportunity to constrain some of those questions, namely the nature of the granite sources and the structural constraints to granite emplacement. In order to achieve these purposes a multidisciplinary approach was undertaken.

This paper reports the petrography, the microstructures, the geochemistry, the U-Pb age and the Anisotropy of Magnetic Susceptibility (AMS) data of the studied pluton. The aim of this study is to provide constraints on the timing of pluton emplacement, its tectonic control and potential sources of these late Variscan granites.

\section{Geological setting}

The Central Iberian zone, CIZ, is the axial domain of the Iberian segment of the Variscan orogenic belt. The tectonic evolution of the 


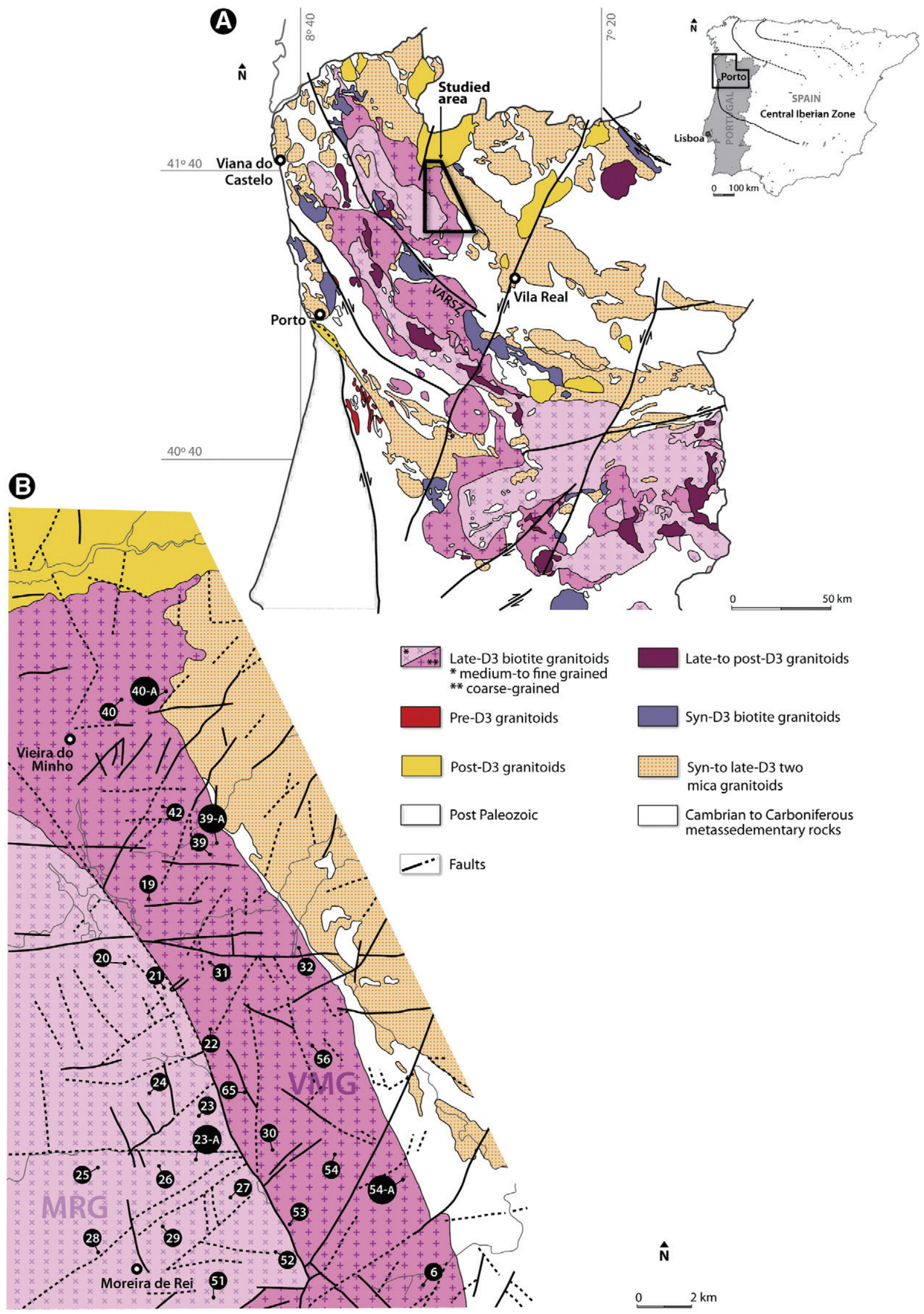

Fig. 1. A) Geological distribution of Variscan syn- to post-orogenic granitoids in the Central Iberian Zone, northern Portugal (Ferreira et al., 1987, modified). Inserted rectangle: studied area. VRSZ - Vigo-Régua shear zone, $\mathrm{D}_{3}$ - last ductile deformation phase; B) geological sketch map of the Vieira do Minho granite (VMG) and the Moreira de Rei granite (MRG), with sampling locations (after Noronha and Lima, 1992). 
Variscan belt, Gondwana-Laurasia collision, and the consequent closure of the Rheic Ocean, has taken place from the Middle-Devonian to the Middle-Carboniferous times followed by post-thickening extension from the Mid-Carboniferous to the Permian. Three main deformation phases $\left(D_{1}, D_{2}\right.$ and $\left.D_{3}\right)$ have been described in this sector of the Variscan belt (Noronha et al., 1979; Ribeiro, 1974; Ribeiro et al., 1983). The $D_{1}$ and the $D_{2}$ deformation phases are related to the maximum of Variscan crustal growth. The late deformation phase, $\mathrm{D}_{3}$, Namurian-Westphalian in age, is correlated to the post-thickening and extension which marked the end of the collision process (Dias and Ribeiro, 1995; Lagarde et al., 1992). The events related to this tectonic phase were marked by vertical folds with subhorizontal axes and strike-slip sinistral and dextral, subvertical shear zones which controlled the large volume of orogenic granitic rocks emplaced in the Central Iberian Zone, (Aguado et al., 2005; Almeida et al., 2002; Dias et al., 1998, 2002; Ferreira et al., 1987; Martins et al., 2009, 2011; Noronha et al., 1979). Based on field and geochronological data, these Variscan granites were divided into two main groups (Dias et al., 1998; Ferreira et al., 1987; Martins et al., 2009, 2011): synorogenic (syn- late and late to post- $\mathrm{D}_{3} ; 320-300 \mathrm{Ma}$ ) and late to post-orogenic (post- ${ }_{3} ; 299-290 \mathrm{Ma}$ ).

The Vieira do Minho pluton, exposed over an area of $1300 \mathrm{~km}^{2}$, is located in the Central Iberian Zone (Julivert et al., 1974), northern Portugal (Fig. 1A), and belongs to a large batholith of late-Variscan granitoids with a NNW-SSE orientation sub-concordant with the regional $\mathrm{D}_{3}$ structures. The distribution of the Vieira do Minho pluton is considered to be tectonically controlled by one of the important structures crossing the Variscan basement in northern Portugal, the $\mathrm{D}_{3}$ Vigo-Régua transtensional shear zone, VRSZ, (Iglesias and Ribeiro, 1981) (Fig. 1A). In the studied sector (Fig. 1B), this pluton crosscuts the peraluminous two-mica syn- $\mathrm{D}_{3}$ granites of Cabeceiras de Basto Complex (Almeida et al., 2002) and a metasedimentary sequence Silurian in age (Ribeiro et al., 2001). At the northern part it was intruded by the post- $\mathrm{D}_{3}$ Gerês Massif (Mendes and Dias, 2004). Contact metamorphism of the studied granitoid pluton is marked by neoformation of biotite and cordierite ( $\mathrm{P}: 2 \mathrm{~kb}, \mathrm{~T}: 550{ }^{\circ} \mathrm{C}$ ) (Ramos et al., 1981) and is superimposed to a regional metamorphism which reaches biotite-andalusite zone (Ramos et al., 1981).

The Vieira do Minho pluton is composite (Fig. 1A) consisting of two biotite-rich porphyritic granite units: a coarse-grained monzogranite, the Vieira do Minho granite (VMG), which occupies a global area of $900 \mathrm{~km}^{2}$, and a medium-grained monzogranite, the Moreira de Rei granite (MRG), occupying $400 \mathrm{~km}^{2}$. In the studied sector these units are exposed over an area of $c a 100 \mathrm{~km}^{2}$ and $c a 60 \mathrm{~km}^{2}$, respectively (Fig. 1B). The VMG is more heterogeneous with a wide variation of megacryst concentrations frequently observed and interpreted as flow magmatic structures. A magmatic fabric is sometimes observed in both granites and is defined by planar orientation of the K-feldspar megacrysts and partially by the biotite. This fabric is related to the magmatic flow whose direction is controlled by the geometry of the intrusion.
Abundant mafic microgranular enclaves, which are rare in the VMG, are present in the MRG with elongate shapes that conform to the magmatic fabric of the granite (Veloso and Dias, 1995). These enclaves have centimetric to metric sizes and present a N40W to N60W trend, sub-concordant with the $\mathrm{D}_{3}$ regional structures. In addition, angular metasedimentary xenoliths are also present at the southern border of the pluton.

The presence of more basic rocks (gabbro-norites, quartz-diorites, and vaugnerites) associated with these granites, especially within the VMG south of the studied area, have been reported by Andrade and Noronha (1981), Dias and Leterrier (1994) and Dias et al. (2002).

Both granitoids are crosscut by pegmatite and aplite dykes intruded as parallel swarms with dominant NE-SW trending. Porphyritic dykes, mostly of basic compositions (lamprophyres), are also present with an ENE-WSW orientation. They have been dated yielding an age (K-Ar) of $189 \pm 9$ Ma (Teixeira and Gonçalves, 1980).

The gradational contact between the VMG and the MRG suggests a synchronous emplacement of the two units.

\section{Petrography and microstructural study}

The main petrographic characteristics of the two granites are reported in Table 1. On the basis of estimated modal compositions, obtained by normative compositions, the two granites are classified as monzogranites; they have a porphyritic hypidiomorphic granular texture and consist mainly of quartz (26-35\%), perthitic K-feldspar $(19-26 \%)$, plagioclase $(30-38 \%)$ and biotite (7-15\%). Muscovite is also present but is rare (1-7\%). Andalusite and cordierite were also observed but only in one sample of the VMG. Apatite, zircon, titanite, ilmenite, monazite (only in VMG) and thorite + allanite (in MRG), can be found as accessory phases.

Quartz is anhedral, typically interstitial, and shows an important recrystallization process, mainly in the VMG. The plagioclase $\left(\mathrm{An}_{34}-\mathrm{An}_{15}\right)$ is euhedral to subhedral and shows oscillatory zoning. However, more sodic composition $\left(\mathrm{An}_{2}-\mathrm{An}_{5}\right)$ may be found in intragranular crystals and in rims that surround the zoned plagioclase and in myrmekitic intergrowths. The albitisation processes (under subsolidus conditions) are common near the contacts and within the K-feldspar crystals which consist of perthitic orthoclase. Microcline can be also present as megacrysts of an earlier growth stage or as interstitial crystals of later formation. They are subhedral or anhedral respectively, cross-hatched twinned and contain inclusions of zoned plagioclase with albite rims, concentrically distributed biotite and globular quartz. Biotite is generally subhedral with reddish-brown to pale yellow pleochroism with abundant inclusions of zircon, apatite, some monazite, ilmenite, rare allanite (in the MRG), rutile and epidote. It sometimes forms polycrystalline aggregates and is locally altered to chlorite. Magmatic muscovite is characterised by subhedral crystals, sometimes overgrowing magmatic biotite and K-feldspar and shows a random orientation. Muscovite crystals with irregular shapes are also observed and were formed below solidus-temperature (secondary muscovite).

Table 1

Normative composition of the Vieira do Minho Granite (VMG) and the Moreira de Rei Granite (MRG).

\begin{tabular}{|c|c|c|c|c|c|c|}
\hline \multirow[b]{2}{*}{$\%$} & \multicolumn{3}{|l|}{ VMG } & \multicolumn{3}{|l|}{ MRG } \\
\hline & Min.-Máx. & Average $n=15$ & $\delta$ & Min.-Máx. & Average $\mathrm{n}=14$ & $\delta$ \\
\hline Quartz & $26.03-34.53$ & 30.58 & 2.55 & $26.10-30.80$ & 28.16 & 1.37 \\
\hline K-feldspar & 19.07-25.95 & 22.20 & 2.07 & $19.01-22.29$ & 20.83 & 1.13 \\
\hline $\begin{array}{l}\text { Plagioclase } \\
\text { (\%An) }\end{array}$ & $\begin{array}{l}29.51-37.34 \\
(14.3-33.8)\end{array}$ & 32.73 & 2.55 & $\begin{array}{l}34.13-37.74 \\
(14.9-33.7)\end{array}$ & 35.18 & 1.50 \\
\hline Biotite & $6.48-14.95$ & 9.2 & 2.59 & $9.25-13.69$ & 11.61 & 1.45 \\
\hline Muscovite & $1.16-6.63$ & 4.22 & 1.66 & $1.9-4.03$ & 2.87 & 0.75 \\
\hline Apatite & $0.21-0.57$ & 0.48 & 0.09 & $0.55-0.67$ & 0.62 & 0.03 \\
\hline Ilmenite & $0.12-0.24$ & 0.20 & 0.07 & $0.19-0.28$ & 0.25 & 0.03 \\
\hline Hematite & $0.02-0.77$ & 0.38 & 0.19 & $0.4-0.71$ & 0.48 & 0.14 \\
\hline
\end{tabular}



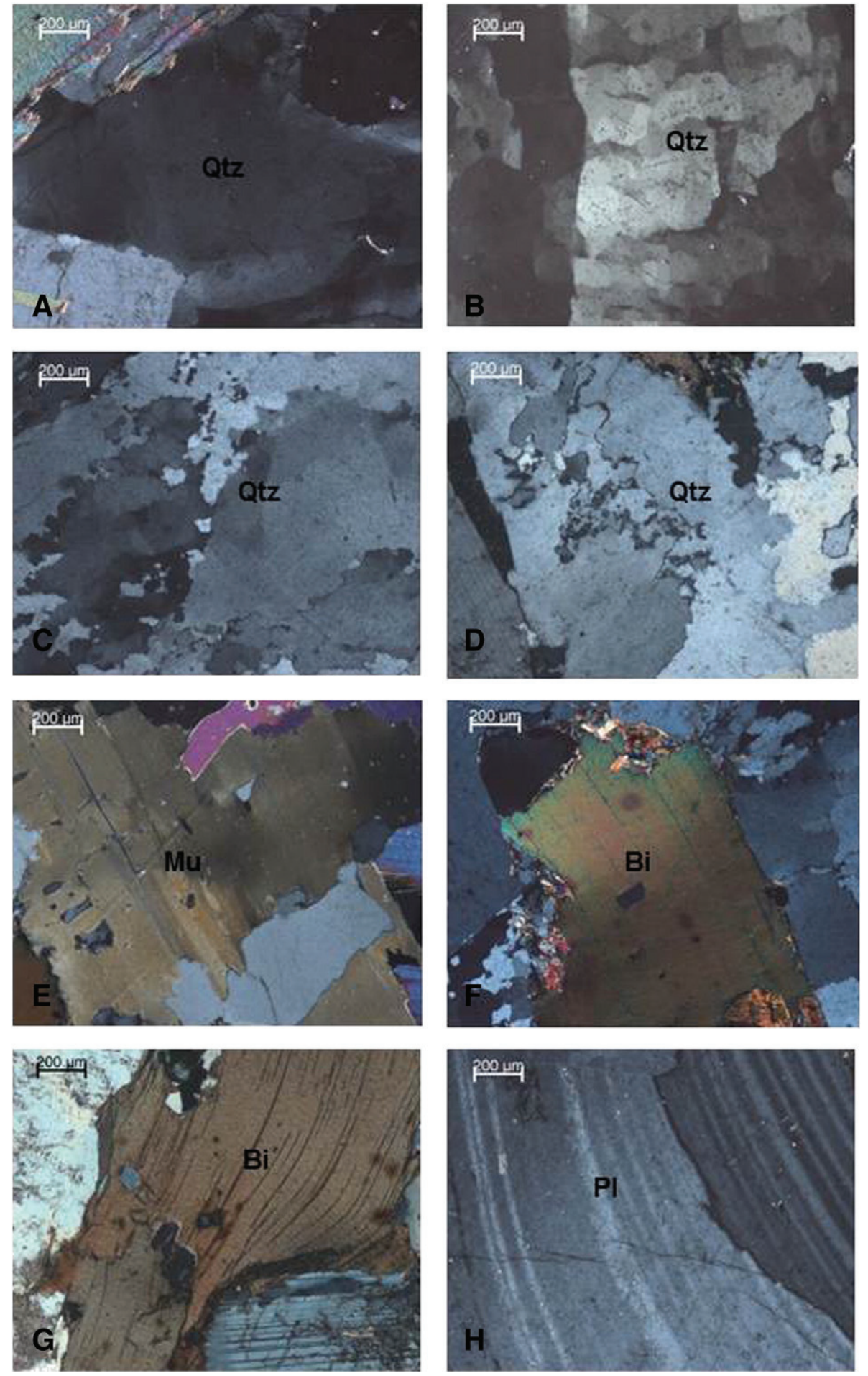

Fig. 2. Details of microstructures. (A) Quartz with undulatory extinction. (B) Quartz with chess-board pattern indicating both (a) and (c) dislocation slip activity during high-temperature deformation. (C) and (D) Polycrystalline quartz aggregate showing an intensive phenomenon of grain boundary migration typical of high temperature deformation. (E) and (f) Muscovite and biotite grains showing undulatory extinction, respectively. (G) Biotite grain with bent cleavage. (H) Plagioclase grain with bent twin plane. The microstructures present in (E), (F), (G) and (H) are indicative of plastic deformation. All microphotographs under crossed polars. Bt: biotite; Pl: plagioclase; Qtz: quartz; Mu: muscovite.

The granites of Vieira do Minho pluton have no visible structure in the field. However granite fabrics study requires the establishment of the microstructures origin, either magmatic or eventually superimposed solid-state. Criteria for this distinction are presented in a number of papers (e. g. Blumenfeld and Bouchez, 1988; Bouchez et al., 1992; Paterson et al., 1989; Vernon, 2000) and the significance of the different microstructures is defined according to magma rheology considerations
(Nicolas, 1992; Vigneresse et al., 1996). When the solid fraction of magma does not exceed a certain amount, about $60 \%$, enough melt is supposed to be present to allow free crystal rotation, i.e. no significant crystal interactions will occur during magma deformation (Arzi, 1978). This behaviour characterises the magmatic state during which magma develops a crystal shape fabric in the course of its emplacement. 
Optical microstructures have been examined in order to determine both the degree of deformation and the physical state of the rock that prevailed during fabric development. The microstructures observed in thin sections of the studied granites show essentially: (i) magmatic microstructures, some undulatory extinction in quartz, (Fig. 2A) and (ii) high temperature microstructures, chess-board pattern (Fig. 2B) and grain boundary migration in quartz grains (Fig. 2C, D), undulatory extinction both in muscovite (Fig. 2E) and biotite crystals (Fig. 2F), bending of biotite cleavages (Fig. 2G) and of plagioclase twin planes (Fig. 2H).

Irregular grain shapes, bowed grain boundaries are often observed in quartz, which are characteristic of a high mobility of the grain boundary at high temperature. Quartz grains also present a chessboard-like texture indicating both (a) and (c) dislocation slip occurring during high temperature deformation (e.g. Gébelin et al., 2006).

\section{Analytical methods}

\subsection{Anisotropy of magnetic susceptibility}

The AMS study sampling was performed in 13 sites in the entire massif, corresponding 6 sites to the MRG and 7 to the VMG, where a total of 3 or 4 oriented cores were collected at each station. The poor exposure conditions within the pluton made an extensive sampling difficult. In the laboratory, each core was sawed in two cylinders and a total of 95 rock-cylinders, $25 \mathrm{~mm}$ in diameter and $22 \mathrm{~mm}$ in length, were obtained and prepared for magnetic measurements. Measurements were performed using KLY-4S Kappabridge susceptometer Agico model (Czech Republic) of "Centro de Geologia" of the Porto University. For each site, the Agico software, ANISOFT, enabled us to calculate the mean susceptibility $\mathrm{Km}$, which is the mean of the eight (or more) individual arithmetic means $(\mathrm{k} 1+\mathrm{k} 2+\mathrm{k} 3) / 3$. With ANISOFT, the intensities and orientations of the three axes $\mathrm{K} 1 \geq \mathrm{K} 2 \geq \mathrm{K} 3$, which are the tensorial means of the $\mathrm{k} 1 \geq \mathrm{k} 2 \geq \mathrm{k} 3$ axes for the eight specimens, were also calculated, as well as the $95 \%$ confidence angles E12, E23 and E31 corresponding to these three axes. The magnetic fabric is defined by the magnetic lineation (parallel to the long axis of the mean ellipsoid orientation average, K1) and the magnetic foliation (plane perpendicular to the orientation of $\mathrm{K} 3$, the short axis). P, the magnetic anisotropy ratio, corresponds to $\mathrm{K} 1 / \mathrm{K} 3$, but in this study we use the parameter $\mathrm{P} \%=((\mathrm{K} 1 / \mathrm{K} 3)-1) \times 100$, (Rochette, 1987). To describe the shape of the AMS ellipsoid the shape parameter, $\mathrm{T}$, expressed by $\mathrm{T}=[2 \ln (\mathrm{K} 2 / \mathrm{K} 3) / \mathrm{ln}(\mathrm{K} 1 / \mathrm{K} 3)]-1$ (Jelinek, 1981) was computed.

\section{2. $U-P b$ dating}

The U-Pb isotopic analyses were carried out at CRPG, Nancy, France, using a conventional $\mathrm{U}-\mathrm{Pb}$ method on multigrain zircon and monazite fractions. The zircons were recovered by crushing of the sample and sieving, followed by heavy liquid and magnetic separations and finally hand picking. Four zircon fractions were selected according to their morphology, colour, and lack of inclusions, fractures and metamictisation. Some of these fractions were submitted to air-abrasion (Krogh, 1982) to eliminate the external zones of the crystal where $\mathrm{Pb}$ loss may have occurred. All zircon fractions were observed by backscattered scanning electron microscopy (BSEM).

Chemical preparation of $\mathrm{U}$ and $\mathrm{Pb}$ analysis includes: (1) $\mathrm{HNO}_{3} 3 \mathrm{~N}$ warm washing of the zircon; (2) $\mathrm{HF}$ digestion at $240{ }^{\circ} \mathrm{C}$ and $\mathrm{HCl} 3 \mathrm{~N}$ dissolution of the fluorides at $180{ }^{\circ} \mathrm{C}$ in a Teflon bomb (Parrish, 1987); (3) separation of $\mathrm{Pb}$ and $\mathrm{U}$ by elution on anionic resin of two aliquots (one with addition of a mixed ${ }^{208} \mathrm{~Pb}-{ }^{235} \mathrm{U}$ spike) following Krogh (1973). Common Pb blanks varied from 30 to 80 pg during this study. The atomic ratios were corrected for initial common lead composition blanks (Stacey and Kramers, 1975) and mass fractionation using NBS 983 Standard. The U-Pb ages with $2 \sigma$ errors were calculated using a version of Isoplot program (Ludwig, 2003). Concordia diagram was constructed using the Isoplot 3 program (Ludwig, 2003). The decay constants used for age determinations are from Steiger and Jäger (1977).

\subsection{Geochemistry}

\subsubsection{Whole rock geochemistry}

Whole-rock chemical compositions of thirty-nine samples have been analysed for major- trace- and rare-earth elements at CRPG, Nancy, France. The samples were fused using $\mathrm{LiBO}_{2}$ and dissolved with $\mathrm{HNO}_{3}$. Solutions were analysed by inductively coupled plasma atomic emission spectrometry (ICP-AES) for major elements, whilst trace elements were determined by ICP mass spectrometry (ICP-MS). Uncertainties in major elements are generally between 1 and $3 \%$, whereas most of the trace elements have uncertainties $<10 \%$. More information on the procedure, precision and accuracy of Nancy ICP-MS analyses is given by Carignan et al. (2001).

\subsection{2. $\mathrm{Sr}-\mathrm{Nd}$ isotopes}

Measurements of $\mathrm{Sr}$ and $\mathrm{Nd}$ isotope values from VMG (three samples) were carried out at the General Research Services of Geochronology and Isotopic Geochemistry (University of the Basque Country/EHU, Spain). Chemical procedures for sample preparation are described in Pin and Bassin (1992), Pin et al. (1994) and Pin and Santos Zalduegui (1997).

$\mathrm{Sm}$ and Nd concentrations were determined by isotope-dilution TIMS using a mixed ${ }^{149} \mathrm{Sm}-{ }^{150} \mathrm{Nd}$ tracer. The ${ }^{147} \mathrm{Sm} /{ }^{144} \mathrm{Nd}$ values are precise to $+/-0.2 \%$ at the $95 \%$ confidence level. The validity of the tracer and the accuracy of the isotope-dilution method were checked by processing and measuring international certified reference materials in the same way as the unknown samples. The obtained Sm and Nd concentrations were within or very close to the recommended values and within the ranges commonly published in peer-reviewed international journals; the ${ }^{147} \mathrm{Sm} /{ }^{144} \mathrm{Nd}$ ratios are also similar to those obtained in other labs by the same technique (e.g., Pin and Santos Zalduegui, 1997).

${ }^{143} \mathrm{Nd} /{ }^{144} \mathrm{Nd}$ ratios were measured by TIMS in a Finnigan MAT-262 instrument in static multicollection mode, and corrected for mass fractionation by normalization to ${ }^{146} \mathrm{Nd} /{ }^{144} \mathrm{Nd}=0.7219$ (Thirlwall, 1991; Wasserburg et al., 1981). Three aliquots of the La Jolla isotopic standard measured under the same conditions gave ${ }^{143} \mathrm{Nd} /{ }^{144} \mathrm{Nd}=$ $0.511878(10)$.

${ }^{87} \mathrm{Sr} /{ }^{86} \mathrm{Sr}$ ratios were measured by MC-ICP-MS using a highresolution Thermo Fisher Scientific Neptune instrument in static multicollection mode, and corrected for mass fractionation by normalization to ${ }^{88} \mathrm{Sr} /{ }^{86} \mathrm{Sr}=8.375209$ (Steiger and Jäger, 1977). The reported ${ }^{87} \mathrm{Sr} /{ }^{86} \mathrm{Sr}$ ratios were adjusted to the NBS 987 standard ${ }^{87} \mathrm{Sr} /{ }^{86} \mathrm{Sr}=$ 0.710264 (9), at the 95\% confidence level (2sigma).

In the calculations of $\varepsilon_{\mathrm{NdT}},{ }^{143} \mathrm{Nd} /{ }^{144} \mathrm{Nd}_{\mathrm{CHUR}}=0.512638$ and ${ }^{147} \mathrm{Sm} /$ ${ }^{144} \mathrm{Nd}_{\mathrm{CHUR}}=0.1967$ (Jacobsen and Wasserburg, 1984) have been used.

\subsubsection{Oxygen isotope}

Oxygen isotope data were performed on two samples analysed for $\mathrm{Sr}$ and $\mathrm{Nd}$ isotopes in the VMG and two selected samples from the MRG at the Stable Isotopic Laboratory of Salamanca, University of Salamanca, Spain. Oxygen was extracted from rocks by laser fluorination techniques, quantitatively converted to $\mathrm{CO}_{2}$ by reaction with a heated carbon rod and analysed for ${ }^{18} \mathrm{O} /{ }^{16} \mathrm{O}$ ratio with a dual inlet VG SIRA-II Mass Spectrometer. The analytical data are reported in the familiar $\delta$-notation referenced to SMOW. Two or more extractions were made on each sample; the reproducibility of isotopic analyses is $\pm 0.1 \%$. NBS-28 yielded an average $\delta^{18} \mathrm{O}$ value of $9.5 \%$ 。 VSMOW. 
Table 2

Anisotropy of magnetic susceptibility data for the sampling sites. Km: mean susceptibility in $10^{-6} \mathrm{SI}$; P\%: anisotropy degree; T: shape parameter (Jelinek, 1981 ); Dec, Inc: Declination, Inclination; E12, E23 and E31: 95\% confidence angles corresponding to the three axes; N: number of specimens.

\begin{tabular}{|c|c|c|c|c|c|c|c|c|c|c|c|c|}
\hline \multirow{2}{*}{$\begin{array}{l}\text { Sampling } \\
\text { sites/lithology }\end{array}$} & \multirow[t]{2}{*}{$\mathrm{Km} 10^{-6} \mathrm{SI}$} & \multirow[t]{2}{*}{$\mathrm{P} \%$} & \multirow[t]{2}{*}{$\mathrm{T}$} & \multicolumn{2}{|l|}{ K1 } & \multicolumn{2}{|l|}{ K3 } & \multirow[t]{2}{*}{ Foliation } & \multirow[t]{2}{*}{ E12 } & \multirow[t]{2}{*}{ E23 } & \multirow[t]{2}{*}{ E31 } & \multirow[t]{2}{*}{$\mathrm{N}$} \\
\hline & & & & $\overline{\text { Dec }}$ & $\overline{\text { Inc }}$ & Dec & $\overline{\text { Inc }}$ & & & & & \\
\hline 23 & 146.8 & 3.2 & -0.113 & 138 & 29 & 244 & 27 & N154; $63 \mathrm{NE}$ & 33 & 33 & 14 & 9 \\
\hline 24 & 154.4 & 3.8 & 0.033 & 168 & 14 & 260 & 6 & $\mathrm{~N} 170 ; 84 \mathrm{NE}$ & 10 & 64 & 11 & 8 \\
\hline 25 & 138.9 & 2.7 & 0.220 & 14 & 36 & 251 & 37 & N161; $53 \mathrm{NE}$ & 19 & 16 & 15 & 6 \\
\hline 26 & 146.9 & 4.1 & 0.269 & 139 & 5 & 233 & 36 & N143; $54 \mathrm{NE}$ & 12 & 6 & 13 & 11 \\
\hline 27 & 150.8 & 3.0 & 0.323 & 62 & 20 & 167 & 35 & N077; 55 NW & 19 & 21 & 21 & 7 \\
\hline 28 & 238.3 & 4.4 & 0.307 & 323 & 25 & 232 & 3 & N142; $87 \mathrm{NE}$ & 5 & 35 & 9 & 8 \\
\hline 31 & 106.0 & 4.8 & 0.037 & 320 & 5 & 61 & 64 & N151; 26 SW & 27 & 12 & 13 & 5 \\
\hline 32 & 155.8 & 6.1 & 0.124 & 148 & 10 & 51 & 32 & $\mathrm{~N} 141 ; 58 \mathrm{SW}$ & 11 & 12 & 11 & 7 \\
\hline 39 & 160.3 & 4.8 & 0.038 & 319 & 0 & 49 & 69 & N139; 21 SW & 37 & 7 & 11 & 6 \\
\hline $39 A$ & 215.3 & 4.9 & 0.081 & 300 & 12 & 45 & 52 & N135; 38 SW & 9 & 30 & 9 & 6 \\
\hline $40 \mathrm{~A}$ & 181.1 & 3.7 & -0.138 & 156 & 4 & 64 & 34 & N154; 56 SW & 12 & 52 & 10 & 6 \\
\hline 42 & 195.2 & 4.8 & 0.013 & 327 & 13 & 82 & 62 & N172; 28 SW & 29 & 28 & 15 & 6 \\
\hline 54 & 110.8 & 4.0 & 0.283 & 164 & 24 & 61 & 28 & N151; 62 SW & 39 & 23 & 17 & 10 \\
\hline
\end{tabular}

\section{Results}

\subsection{Anisotropy of Magnetic Susceptibility (AMS)}

An Anisotropy of Magnetic Susceptibility (AMS) study was conducted to characterise magnetic mineralogy and acquire a data set for the fabrics of the Vieira do Minho granite. The results for the thirteen stations are summarised in Table 2 . The $\mathrm{Km}, \mathrm{P} \%$ and $\mathrm{T}$ values are similar for both granites. The average susceptibility values $(\mathrm{Km})$ are between 106 and $215 \times 10^{-6}$ SI (mean: $161.6 \times 10^{-6}$ ), characterising paramagnetic minerals as the principal carrier of magnetic susceptibility. The magnetic mineralogy is, therefore, dominated by paramagnetic minerals such as biotite, which is easily observed in thin section and which is the main Fe-bearing mineral. The magnetic anisotropy expressed by the parameter P\% is between 2.7 and 6.1\% (mean: $4.2 \%$ ). The AMS ellipsoid shape parameter indicates ellipsoids dominantly oblate (mean: 0.114). Benn (1994) demonstrated experimentally that the AMS ellipsoid becomes increasingly flatter, as the strain increases, mainly for a magnetic anisotropy higher than $4 \%$. In the studied granites we have 6 stations where $\mathrm{P} \%>4 \%$. However, in the studied granites, the plot of the $\mathrm{T}$ and $\mathrm{P} \%$ parameters showed that no relationship AMS ellipsoid and the magnetic anisotropy is established (Fig. 3).

Once, the magnetic signal is mainly attributed to the biotite, the $\mathrm{K} 1$ and $\mathrm{K} 3$ axes may be directly interpreted as the lineation and the pole of foliation of the mineral fabrics, respectively (Rochette et al., 1992). The magnetic lineation (K1) and the pole of the magnetic foliation (K3) are plotted on an equal-area and lower hemispheric projection (Fig. 4). Most of the sites show well-grouped K1 and K3 axes projection and low $95 \%$ confidence angles (Table 2, Fig. 4). Despite the similarity for the $\mathrm{Km}, \mathrm{P} \%$ and $\mathrm{T}$ values in the MRG and the VMG, the AMS fabric patterns are different for the two units: in the MRG magnetic foliations are NW-SE-trending with very steep dips ranging from 53 to 87 to NE. However, in the VMG magnetic foliations are NW-SE trending dipping to SW with dips ranging from 21 to 62. Most magnetic lineations are NW-SE-trending with shallow plunges (Fig. 4) and in three sites of the MRG have shallow plunges to NE.

\section{2. $U-P b$ geochronology}

The $\mathrm{U}-\mathrm{Pb}$ isotopic age determination was carried out on three zircon fractions and one fraction of monazite only for the VMG and the results are given in Table 3. All zircon fractions are limpid and colourless to pale yellow. The monazite is subhedral, very limpid and with light yellow colour. A morphological study using the zircon typology (Pupin, 1980) was carried out and allows the identification of several zircon types, indicating a crustal or dominantly crustal origin for the VMG and an hybrid calc-alkaline magma for the MRG (Martins and Noronha, 2000a).

According to their morphology four different populations of zircon have been recognized in the VMG: prismatic zircons (short, long and acicular), lamellar zircons and a less common subspherical multifaceted zircons which are included in short prismatic fraction. The internal structures (BSME images) of the zircons show typical magmatic structures, with an inner zone with oscillatory internal structures

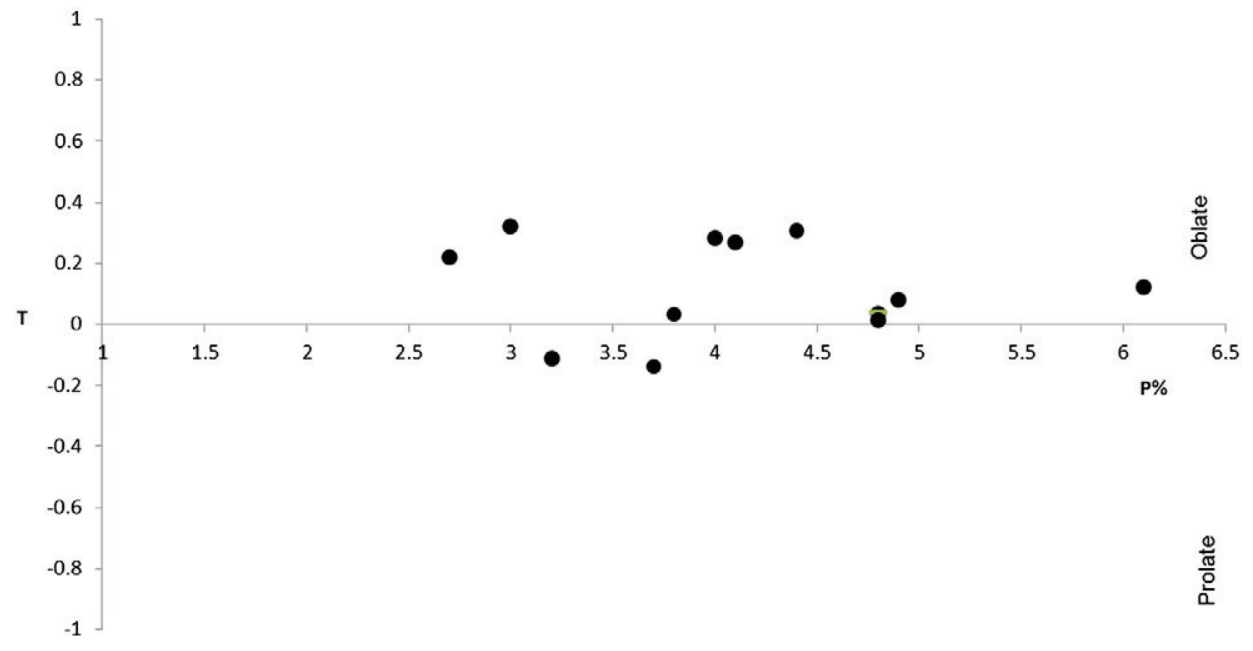

Fig. 3. Plots of the shape (T) and anisotropy (P\%) parameters showing dominant oblate ellipsoids. 


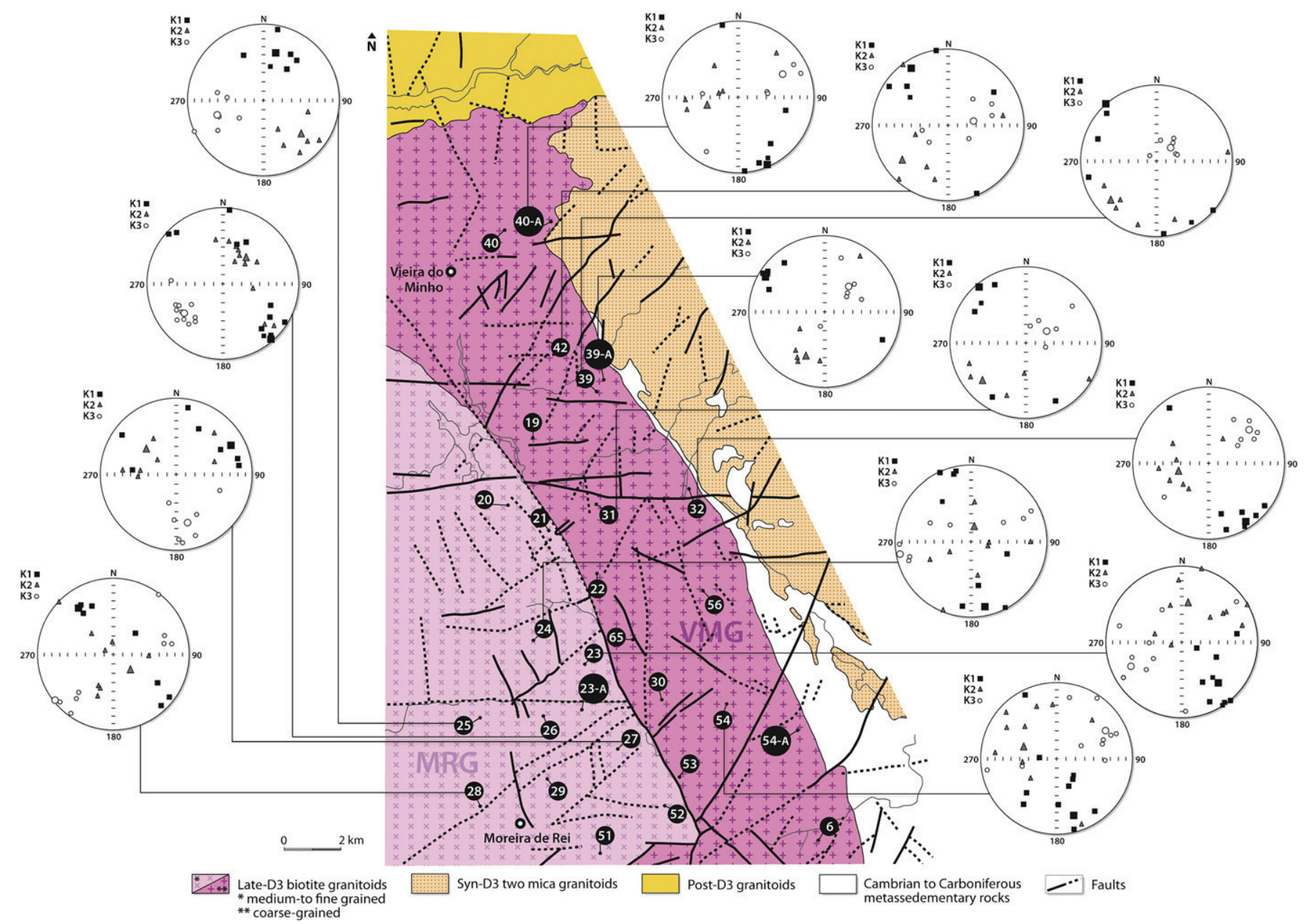

Fig. 4. Simplified geological map of the studied area with the sampling sites and the stereoplots (Schmidt, lower hemisphere projection) of the three axes of the AMS ellipsoid within the Vieira do Minho granite (VMG) and the Moreira de Rei granite (MRG). Squares and circles are K1 (magnetic lineation) and K3 (pole of magnetic foliation), respectively.

surrounded by regular fine magmatic zoning. These structures are common in long prismatic zircons. The prismatic acicular and the lamellar zircons are very homogeneous crystals devoid of cores and showing generally a faint zoning dominantly oscillatory internal structures. The BSME imaging of the subspherical type reveal the presence of inherited cores.

The analytical points of three zircon and monazite fractions are concordant and define a line (MSWD of concordance $=0.045$, probability of fit $=0.99$ ) intersecting the Concordia at $310 \pm 2 \mathrm{Ma}$ (Fig. 5). The monazite is slightly reversely discordant giving a ${ }^{207} \mathrm{~Pb} /{ }^{235} \mathrm{U}$ age of $312 \pm 2$ Ma which is in good agreement with the age obtained for zircon fractions. It must be noted (Table 3 ) that one zircon fraction (short prismatic, including multifaceted subspherical) is largely discordant with ${ }^{207} \mathrm{~Pb} /{ }^{206} \mathrm{~Pb}$ age of $647 \mathrm{Ma}$. This discordance is interpreted as indicating the presence of inherited lead, which is confirmed by the observed cores in BSEM images.

The U-Pb isotopic data for the MRG was obtained by Dias et al (1998) yielding an age of $307 \pm 3.5 \mathrm{Ma}$ (upper intercept). These data led us to consider that the $310 \pm 2 \mathrm{Ma}$ and the $307 \pm 3.5$ values are likely to be the age of emplacement and crystallisation of the monzogranites.

Table 3

$\mathrm{U}-\mathrm{Pb}$ isotopic data on zircon (zr) and monazite (mz) fractions from the Vieira do Minho Granite (VMG).

\begin{tabular}{|c|c|c|c|c|c|c|c|c|c|c|}
\hline \multirow[b]{2}{*}{$\begin{array}{l}\text { Fractions } \\
\text { (shape) }\end{array}$} & \multirow[b]{2}{*}{$\begin{array}{l}\text { Weight } \\
\text { (mg) }\end{array}$} & \multicolumn{3}{|c|}{ CONCENTRATIONS } & \multicolumn{3}{|l|}{ ISOTOPIC RATIOS } & \multicolumn{3}{|c|}{ APPARENT AGES (Ma) } \\
\hline & & $\begin{array}{l}\text { U Total } \\
(\mathrm{ppm})\end{array}$ & $\begin{array}{l}\mathrm{Pb}^{*} \\
(\mathrm{ppm})\end{array}$ & ${ }^{206} \mathrm{~Pb} /{ }^{204} \mathrm{~Pb}$ & $\begin{array}{l}{ }^{206} \mathrm{~Pb}^{*} / 238 \mathrm{U} \\
2 \sigma(\%)\end{array}$ & $\begin{array}{l}{ }^{207} \mathrm{~Pb}^{*} / 235 \mathrm{U} \\
2 \sigma(\%)\end{array}$ & $\begin{array}{l}{ }^{07} \mathrm{~Pb}^{*} /{ }^{206} \mathrm{~Pb} \\
2 \sigma(\%)\end{array}$ & $\begin{array}{l}{ }^{206} \mathrm{~Pb}^{*} /{ }^{238} \mathrm{U} \\
2 \sigma\end{array}$ & $\begin{array}{l}{ }^{207} \mathrm{~Pb}^{*} /{ }^{235} \mathrm{U} \\
2 \sigma\end{array}$ & $\begin{array}{l}{ }^{07} \mathrm{~Pb}^{*} /{ }^{206} \mathrm{~Pb}^{*} \\
2 \sigma\end{array}$ \\
\hline $6 \mathrm{C}-40(\mathrm{Mz})$ & 0.34 & 2692.3 & 1102.7 & 4651 & $0.049582 \pm 0.691$ & $0.359383 \pm 0.797$ & $0.052569 \pm 0.108$ & $312 \pm 2.1$ & $311.8 \pm 2.1$ & $308 \pm 4$ \\
\hline $\begin{array}{l}\text { 6C-40/A (Z) na } \\
\text { (needle) }\end{array}$ & 0.82 & 809.4 & 35.5 & 3856 & $0.045164 \pm 0.116$ & $0.327276 \pm 0.239$ & $0.052556 \pm 0.128$ & $284.8 \pm 0.3$ & $287.5 \pm 0.6$ & $310 \pm 2$ \\
\hline $\begin{array}{l}\text { 6C-40/B (Z) na } \\
\text { (Lamellar) }\end{array}$ & 0.45 & 757.7 & 33.6 & 2596 & $0.046459 \pm 0.101$ & $0.336607 \pm 0.251$ & $0.052547 \pm 0.157$ & $292.7 \pm 0.3$ & $294.6 \pm 0.6$ & $309 \pm 2$ \\
\hline $\begin{array}{l}\text { 6C-40/C (Z) a } \\
\quad \text { (short prisms) }\end{array}$ & 0,36 & 592.2 & 32.1 & 1387 & $0.055266 \pm 0.110$ & $0.466558 \pm 0.237$ & $0.061227 \pm 0.133$ & $346.8 \pm 0.4$ & $388.8 \pm 0.8$ & $647 \pm 3$ \\
\hline $\begin{array}{l}\text { 6C-40/D (Z) a } \\
\quad \text { (long prisms) }\end{array}$ & 0.57 & 757.2 & 34,6 & 2382 & $0.047598 \pm 0.113$ & $0.344911 \pm 0.220$ & $0.052556 \pm 0.111$ & $299.8 \pm 0.3$ & $300.9 \pm 0.6$ & $310 \pm 2$ \\
\hline
\end{tabular}

a: fraction submitted to abrasion; na: fraction not submitted to abrasion; $\mathrm{Pb}^{*}$ radiogenic lead. 


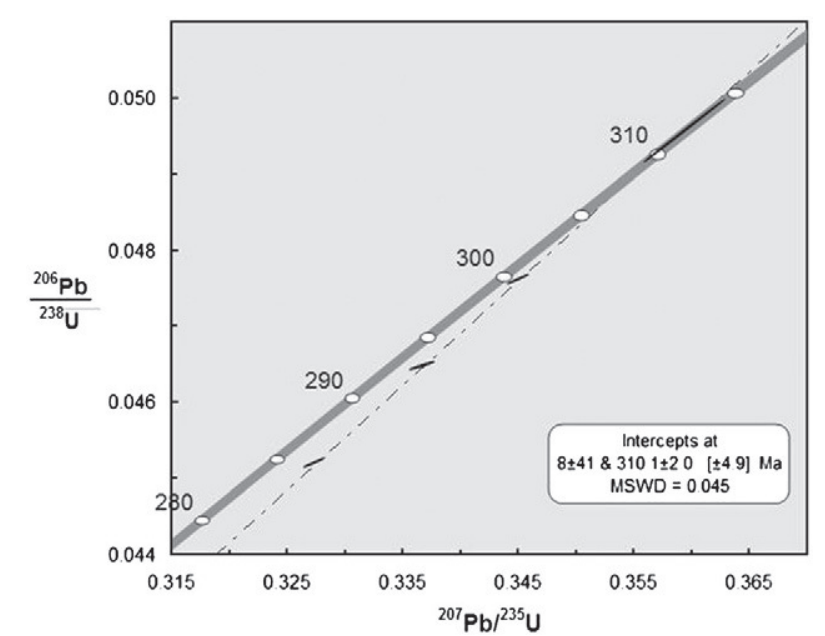

Fig. 5. Concordia diagram showing analytical data for zircon and monazite fractions from one sample (6C-40) of the Vieira do Minho granite (VMG).

\subsection{Geochemistry}

\subsubsection{Whole rock and mineral geochemistry}

Representative major- trace- and rare-earth data from collected samples of the two granites studied, VMG and MRG, are reported in Table 4.

The VMG and the MRG are characterised by a high and restricted $\mathrm{SiO}_{2}$ range of 67-73 wt.\%. With slightly lower average $\mathrm{SiO}_{2}$, the MRG has somewhat higher $\mathrm{MgO}$ and $\mathrm{TiO}_{2}$ concentrations than the VMG. They have, on the other hand, a potassic signature with $\mathrm{K}_{2} \mathrm{O}$ / $\mathrm{Na}_{2} \mathrm{O}$ ratio ranging from 1.57 to 1.84 in the VMG and $1.51-1.70$ in the MRG. Both granites reveal a peraluminous character with aluminium saturation index A/CNK ranging from 1.05-1.16 and 1.05-1.09 in the VMG and in the MRG, respectively. The similarities in the major element oxides and some of trace elements can be easily observed in the variation diagrams (Fig. 6). The VMG, which presents a wide range of geochemical variations, shows a decrease of $\mathrm{Al}_{2} \mathrm{O}_{3}, \mathrm{CaO}$, $\mathrm{Fe}_{2} \mathrm{O}_{3}, \mathrm{MgO}, \mathrm{TiO}_{2}$ and $\mathrm{Zr}$ while $\mathrm{SiO}_{2}$ increasing, indicating biotite, ilmenite and zircon fractionation during the magmatic evolution. A similar evolution trend was observed in the MRG (Fig. 6). According to the classification proposed by Frost et al. (2001) these granites are peraluminous (Fig. 7) and belong to the alkali-calcic series. However, the VMG plots mostly in the ferroan field and the GMR in the magnesian field (Fig. 8).

Table 4

Major (wt.\%), trace and rare earth (ppm) elements data of samples from the Vieira do Minho Granite (VMG) and the Moreira de Rei Granite (MRG)

\begin{tabular}{|c|c|c|c|c|c|c|c|c|c|c|c|c|c|c|}
\hline \multicolumn{15}{|l|}{ VMG } \\
\hline Sample & $6 C-22$ & $6 C-32$ & $6 C-42$ & $6 C-55$ & $6 C-56$ & $6 C-39$ & $6 C-39 A$ & $6 C-53$ & $6 C-19$ & $6 C-31$ & $6 C-6$ & $6 C-30$ & $6 C-40$ & $6 C-40 A$ \\
\hline $\mathrm{SiO} 2$ & 72.56 & 70.18 & 70.29 & 72.47 & 72.36 & 67.74 & 66.71 & 71.56 & 70.54 & 69.73 & 72.34 & 72.21 & 69.44 & 67.39 \\
\hline TiO2 & 0.32 & 0.40 & 0.67 & 0.47 & 0.54 & 0.60 & 0.64 & 0.40 & 0.68 & 0.59 & 0.35 & 0.44 & 0.66 & 0.70 \\
\hline $\mathrm{Al} 2 \mathrm{O} 3$ & 13.86 & 14.68 & 14.73 & 13.71 & 13.71 & 15.17 & 15.83 & 13.92 & 14.73 & 14.83 & 13.61 & 14.04 & 14.65 & 15.12 \\
\hline $\mathrm{Fe} 2 \mathrm{O} 3 \mathrm{t}$ & 2.50 & 3.04 & 3.17 & 2.68 & 2.84 & 4.19 & 4.21 & 2.97 & 3.12 & 3.52 & 2.47 & 2.47 & 3.68 & 4.61 \\
\hline $\mathrm{MnO}$ & 0.02 & 0.03 & 0.03 & 0.03 & 0.03 & 0.04 & 0.04 & 0.02 & 0.03 & 0.05 & 0.03 & 0.04 & 0.06 & 0.05 \\
\hline $\mathrm{MgO}$ & 0.44 & 0.60 & 0.71 & 0.56 & 0.61 & 0.91 & 0.94 & 0.56 & 0.69 & 0.87 & 0.52 & 0.32 & 0.62 & 1.03 \\
\hline $\mathrm{CaO}$ & 1.12 & 1.56 & 1.29 & 0.88 & 1.10 & 2.08 & 1.92 & 1.22 & 0.95 & 1.60 & 1.15 & 1.09 & 1.94 & 2.05 \\
\hline $\mathrm{Na} 2 \mathrm{O}$ & 2.91 & 3.20 & 2.95 & 2.89 & 2.76 & 3.12 & 3.19 & 2.87 & 2.79 & 3.06 & 2.92 & 3.07 & 3.32 & 3.06 \\
\hline K2O & 5.15 & 5.15 & 4.80 & 5.11 & 4.85 & 4.91 & 5.30 & 5.19 & 5.18 & 5.09 & 5.05 & 5.17 & 4.77 & 4.85 \\
\hline P2O5 & 0.20 & 0.22 & 0.23 & 0.23 & 0.22 & 0.26 & 0.27 & 0.24 & 0.27 & 0.25 & 0.19 & 0.24 & 0.29 & 0.27 \\
\hline LOI & 0.68 & 0.62 & 0.49 & 0.57 & 0.46 & 0.65 & 0.72 & 0.72 & 0.50 & 0.79 & 0.76 & 0.66 & 0.70 & 0.60 \\
\hline Total & 99.76 & 99.68 & 99.36 & 99.60 & 99.48 & 99.67 & 99.77 & 99.67 & 99.48 & 100.38 & 99.39 & 99.09 & 100.13 & 99.73 \\
\hline $\mathrm{A} / \mathrm{CNK}$ & 1.12 & 1.07 & 1.19 & 1.15 & 1.16 & 1.07 & 1.09 & 1.11 & 1.24 & 1.10 & 1.10 & 1.11 & 1.04 & 1.08 \\
\hline $\mathrm{Ba}$ & 394 & 557 & 738 & 425 & 675 & 826 & 1134 & 447 & 513 & 589 & 410 & 384 & 783 & 828 \\
\hline $\mathrm{Rb}$ & 280 & 232 & 248 & 278 & 248 & 232 & 225 & 249 & 319 & 285 & 268 & 268 & 254 & 216 \\
\hline $\mathrm{Sr}$ & 102.0 & 146.0 & 175.0 & 102.0 & 125.0 & 208.0 & 207.0 & 113.0 & 128.0 & 185.0 & 192.0 & 202.0 & 247.0 & 183.0 \\
\hline Cs & 16.0 & 10.7 & 19.0 & 19.0 & 18.0 & 9.1 & nd & 23 & 18.0 & nd & nd & nd & nd & 13.2 \\
\hline $\mathrm{Li}$ & 100 & 95 & 86 & 94 & 85 & 84 & 73 & 89 & 94 & 76 & 64 & 84 & 71 & 82 \\
\hline Co & $<5$ & 5.00 & 36.00 & 33.00 & 33.00 & 8.00 & 6.62 & 6.00 & 33.00 & nd & nd & nd & nd & 7.00 \\
\hline $\mathrm{Cr}$ & 96.0 & 103.0 & 106.0 & 108.0 & 108.0 & 128.0 & 79.8 & 135.0 & 118.0 & nd & nd & nd & nd & 84.8 \\
\hline $\mathrm{F}$ & 1250 & 1350 & nd & nd & 1450 & 1750 & nd & nd & nd & nd & nd & 1300 & nd & 1750 \\
\hline Sn & 15.0 & 10.0 & nd & nd & 79.0 & 19.0 & nd & nd & nd & nd & nd & 7.0 & nd & 12.0 \\
\hline W & 3.2 & 2.5 & nd & nd & 2.6 & 3.1 & nd & nd & nd & nd & nd & 1.0 & 1.2 & 2.4 \\
\hline $\mathrm{Nb}$ & 12.8 & 15.3 & nd & nd & 14.8 & 17.7 & 16.0 & $<5$ & nd & nd & nd & 15.1 & nd & 18.8 \\
\hline $\mathrm{Zr}$ & 150 & 202 & nd & nd & 226 & 285 & 279 & 190 & nd & nd & nd & 166 & nd & 312 \\
\hline $\mathrm{Ga}$ & 17.0 & 16.0 & nd & nd & 21.0 & 21.0 & 24.0 & 14.0 & nd & nd & nd & nd & nd & 23.4 \\
\hline Th & 20.0 & 21.0 & nd & nd & 27.3 & 26.0 & 24.0 & 22.0 & nd & nd & nd & nd & nd & 28.9 \\
\hline Y & 14.0 & 20.0 & nd & nd & 27.0 & 28.0 & 27.6 & 19.0 & nd & nd & nd & nd & nd & 34.0 \\
\hline V & 19.0 & 27.0 & nd & nd & 22.0 & 38.0 & 39.0 & 22.0 & nd & nd & nd & nd & nd & 42.8 \\
\hline $\mathrm{Be}$ & 3.90 & 1.60 & nd & nd & 4.00 & 2.20 & 3.00 & 1.70 & nd & nd & nd & nd & nd & 3.00 \\
\hline $\mathrm{Ta}$ & 1.41 & 1.45 & nd & nd & 1.28 & 1.45 & nd & nd & nd & nd & nd & nd & nd & 1.85 \\
\hline U & 4.71 & 4.39 & nd & nd & 2.56 & 4.76 & nd & nd & nd & nd & nd & nd & nd & 4.46 \\
\hline $\mathrm{Hf}$ & 5.10 & 6.20 & nd & nd & 6.50 & 7.90 & nd & nd & nd & nd & nd & nd & nd & 9.00 \\
\hline $\mathrm{La}$ & 31.78 & 45.26 & nd & nd & nd & 57.90 & 58.24 & 39.56 & nd & nd & nd & 37.92 & 71.05 & 70.81 \\
\hline $\mathrm{Ce}$ & 63.84 & 86.05 & nd & nd & nd & 115.48 & 112.50 & 71.09 & nd & nd & nd & 80.71 & 145.41 & 137.40 \\
\hline $\mathrm{Nd}$ & 27.79 & 37.24 & nd & nd & nd & 50.44 & 51.30 & 32.24 & nd & nd & nd & 30.78 & 55.25 & 63.64 \\
\hline $\mathrm{Sm}$ & 6.32 & 7.83 & nd & nd & nd & 10.26 & 9.25 & 7.50 & nd & nd & nd & 6.85 & 11.73 & 11.06 \\
\hline $\mathrm{Eu}$ & 0.87 & 1.16 & nd & nd & nd & 1.59 & 1.64 & 1.02 & nd & nd & nd & 1.06 & 2.04 & 1.52 \\
\hline Gd & 5.14 & 5.76 & nd & nd & nd & 7.93 & 6.92 & 5.88 & nd & nd & nd & 4.93 & 8.25 & 9.21 \\
\hline Dy & 3.64 & 4.16 & nd & nd & nd & 5.98 & 5.52 & 3.99 & nd & nd & nd & 3.77 & 5.99 & 6.65 \\
\hline $\mathrm{Er}$ & 1.37 & 1.72 & nd & nd & nd & 2.68 & 2.39 & 1.59 & nd & nd & nd & 1.56 & 3.18 & 2.92 \\
\hline $\mathrm{Yb}$ & 1.11 & 1.82 & nd & nd & nd & 2.97 & 2.66 & 1.23 & nd & nd & nd & 1.29 & 3.58 & 2.82 \\
\hline $\mathrm{Lu}$ & 0.18 & 0.24 & nd & nd & nd & 0.48 & 0.40 & 0.21 & nd & nd & nd & 0.20 & 0.53 & 0.43 \\
\hline
\end{tabular}

nd: Not determined. 
Both granites present a moderate REE fractionated patterns, with $(\mathrm{La} / \mathrm{Yb})_{\mathrm{N}}$ ranging from 13.16 to 21.71 and 17.64 to 21.20 in the VMG and the MRG, respectively. The REE patterns are similar in both units and the MRG fall entirely within the field of VMG REE patterns. They have also a negative Eu anomaly in the same range, $\mathrm{Eu} / \mathrm{Eu}^{*}=0.45-$ 0.60 in the VMG and $\mathrm{Eu} / \mathrm{Eu}^{*}=0.42-0.61$ in the MRG (Fig. 9).

Multi-element diagram normalized to the primitive mantle show also very similar patterns and a remarkable superposition of the two granites, with positive $\mathrm{Rb}$, Th, and $\mathrm{Nd}$ anomalies and negative $\mathrm{Ba}, \mathrm{Nb}, \mathrm{Sr}$ and Ti anomalies (Fig. 10). The presence of $\mathrm{Ba}$ and $\mathrm{Sr}$ anomalies, suggest, together with a negative Eu anomaly (Fig. 9), that these granites crystallized from magmas that underwent significant feldspar crystallization or partial melting of the parental rocks with residual feldspar.

Although the whole rock geochemical data are very similar in both granites, the VMG is comparatively depleted in MgO. The geochemical data rule out a simple fractional crystallization relation between the VMG and the MRG, which might represent two different magma batches. This is also corroborated by the biotite composition of the two granites which differ mainly by its $\mathrm{Mg}$ and $\mathrm{Al}$ content (Martins and Noronha, 2000b). The biotites of the VMG are more aluminous $\left(\mathrm{Al}_{\mathrm{t}}=3.25-3.65 \mathrm{apfu}\right)$ and less magnesian $(\mathrm{XMg}=0.30-0.38)$, than the biotites from the MRG $\left(\mathrm{Al}_{\mathrm{t}}=3.11-3.35 \mathrm{apfu}\right.$ and $\mathrm{XMg}=0.38-$ 0.45).
Geochemical and mineralogical data suggest that these granites share common features typical of peraluminous granite suites. The felsic nature of the studied Variscan plutons contrasts with Mesozoic cordilleran batholiths, which are more metaluminous, magnesian and Na-rich granites (e.g. Frost et al., 2001).

\subsubsection{Whole rock isotopic data}

The isotopic results, along with the calculated initial ${ }^{87} \mathrm{Sr} /{ }^{86} \mathrm{Sr}$ and $\varepsilon_{\mathrm{Nd}}$ values are given in Table 5 .

The available isotopic data from the MRG were obtained by Dias et al. (2002). This granite presents a $\left({ }^{87} \mathrm{Sr} /{ }^{86} \mathrm{Sr}\right)_{\mathrm{i}}$ between 0.7070 and 0.7075 with initial $\varepsilon_{\mathrm{Nd}}=-6.0$ to -5.2 (Table 5). The VMG shows a slightly more enriched isotopic signature with $\left({ }^{87} \mathrm{Sr} /{ }^{86}\right.$ $\mathrm{Sr})_{\mathrm{i}}$ ranging mostly from 0.7087 to 0.7098 and $\varepsilon_{\mathrm{Nd}}$ from -5.5 to -5.2 (Table 5). Sample 6C-30 shows a markedly higher $\left({ }^{87} \mathrm{Sr} /{ }^{86}\right.$ $\mathrm{Sr}$ ) ratio at $310 \mathrm{Ma}$, suggesting an isotopic heterogeneity in the VMG (Table 5). Isotopic Sr, Nd signatures from the studied granites are very similar to those found in other syn-to-post-D3 Variscan granites from northern Portugal, and also from other areas of the Central Iberian Zone (e.g. Bea et al., 1999; Dias et al., 2002; Villaseca et al., 1998, 2008).

Whole-rock oxygen isotope $\left(\delta^{18} \mathrm{O}\right.$ VSMOW $)$ values, for four representative samples of the studied granites, range from $+10.6 \%$ to $+11.0 \%$ in the VMG through to $+9.9 \%$ o to $+10.5 .0 \%$ in the MRG.

\begin{tabular}{|c|c|c|c|c|c|c|c|c|c|c|c|c|c|}
\hline \multirow[b]{2}{*}{$6 C-54 \mathrm{~A}$} & \multirow[b]{2}{*}{$6 C-54$} & \multicolumn{12}{|l|}{ MRG } \\
\hline & & $6 C-23$ & $6 C-23 A$ & $6 C-25$ & $6 C-26$ & $6 C-51$ & $6 C-52$ & $6 C-21$ & $6 C-20$ & $6 C-27$ & $6 C-28$ & $6 C-29$ & $6 C-24$ \\
\hline 72.80 & 70.87 & 69.90 & 69.12 & 69.74 & 70.85 & 70.30 & 69.60 & 68.65 & 69.43 & 68.83 & 68.47 & 69.66 & 70.34 \\
\hline 0.35 & 0.49 & 0.69 & 0.50 & 0.56 & 0.72 & 0.66 & 0.56 & 0.65 & 0.58 & 0.64 & 0.70 & 0.61 & 0.51 \\
\hline 13.22 & 13.81 & 14.73 & 14.31 & 14.28 & 13.71 & 14.56 & 14.85 & 14.38 & 14.78 & 14.34 & 15.27 & 14.66 & 14.11 \\
\hline 2.57 & 3.84 & 3.24 & 3.15 & 3.44 & 3.32 & 3.22 & 3.15 & 4.12 & 3.17 & 3.21 & 3.74 & 3.35 & 3.34 \\
\hline 0.02 & 0.05 & 0.04 & 0.04 & 0.04 & 0.04 & 0.04 & 0.04 & 0.04 & 0.05 & 0.05 & 0.06 & 0.05 & 0.05 \\
\hline 0.46 & 0.68 & 0.83 & 0.81 & 0.96 & 0.89 & 0.88 & 0.79 & 0.91 & 0.71 & 1.03 & 1.15 & 0.96 & 0.81 \\
\hline 1.18 & 1.24 & 1.18 & 1.58 & 1.77 & 1.20 & 1.21 & 1.10 & 1.27 & 0.74 & 1.56 & 2.10 & 1.66 & 1.58 \\
\hline 3.00 & 2.95 & 2.98 & 3.00 & 3.02 & 2.81 & 2.81 & 2.84 & 2.75 & 2.83 & 3.09 & 3.22 & 3.12 & 3.00 \\
\hline 5.07 & 4.83 & 5.01 & 4.99 & 4.97 & 5.10 & 4.95 & 5.59 & 5.12 & 5.19 & 5.01 & 4.85 & 4.93 & 4.94 \\
\hline 0.10 & 0.25 & 0.31 & 0.27 & 0.29 & 0.27 & 0.30 & 0.26 & 0.68 & 0.33 & 0.30 & 0.30 & 0.29 & 0.29 \\
\hline 0.59 & 0.58 & 0.55 & 0.91 & 0.65 & 0.63 & 0.61 & 0.66 & 1.10 & 1.83 & 0.78 & 0.63 & 0.78 & 0.71 \\
\hline 99.36 & 99.59 & 99.46 & 98.68 & 99.72 & 99.54 & 99.54 & 99.44 & 99.67 & 99.64 & 98.84 & 100.49 & 100.07 & 99.68 \\
\hline 1.05 & 1.12 & 1.18 & 1.08 & 1.05 & 1.11 & 1.20 & 1.17 & 1.16 & 1.27 & 1.07 & 1.06 & 1.09 & 1.07 \\
\hline 650 & 411 & 638 & 482 & 614 & 650 & 712 & 813 & 708 & 510 & 515 & 601 & 577 & 497 \\
\hline 269 & 244 & 315 & 283 & 317 & 335 & 286 & 330 & 293 & 366 & 332 & 294 & 324 & 319 \\
\hline 120.0 & 234.0 & 143.0 & 138.0 & 177.0 & 156.0 & 136.0 & 120.0 & 155.0 & 148.0 & 277.0 & 305.0 & 200.0 & 146.0 \\
\hline 9.0 & nd & 30.0 & 17.7 & 23.1 & 23.0 & 30.0 & 33.0 & 14.1 & nd & nd & nd & 30 & 19.3 \\
\hline 64 & 85 & 128 & nd & 138 & 120 & 109 & 116 & 105 & 127 & 116 & 102 & 119 & 125 \\
\hline 4.00 & nd & 44.00 & 4.93 & 6.00 & 33.00 & 23.00 & 26.00 & 6.00 & $<5$ & 7.00 & nd & 28 & 6.00 \\
\hline 73.0 & nd & 63.0 & 91.3 & 83.0 & 68.0 & 87.0 & 74.0 & 99.0 & 15.0 & 21.0 & nd & 88 & 120.0 \\
\hline 1250 & 1500 & 1850 & nd & 1650 & nd & 1750 & nd & 1450 & nd & 1900 & 2000 & nd & 1850 \\
\hline 7.0 & 6.5 & 16.0 & 10.0 & 18.0 & nd & 14.0 & nd & 15.0 & nd & 10.0 & 11.0 & nd & 13.0 \\
\hline 1.8 & 1.3 & 2.7 & 2.0 & 2.9 & nd & 2.6 & nd & 2.6 & 2.1 & 1.8 & 1.4 & nd & 3.0 \\
\hline 12.9 & 18.9 & 19.3 & 15.0 & 20.0 & nd & 18.7 & nd & 16.0 & 11.0 & 16.2 & 20.7 & nd & 17.3 \\
\hline 222 & 241 & 249 & 213 & 226 & nd & 248 & nd & 265 & 203 & 232 & 248 & nd & 211 \\
\hline 20.0 & nd & 24.0 & 21.7 & 15.0 & nd & 27.0 & nd & 21.0 & 21.0 & 19.0 & nd & nd & 18.0 \\
\hline 23.6 & nd & 31.2 & 26.8 & 24.0 & nd & 26.7 & nd & 31.0 & 33.0 & 24.0 & nd & nd & 27.0 \\
\hline 21.0 & nd & 23.0 & 21.5 & 18.0 & nd & 25.0 & nd & 23.0 & 17.0 & 19.0 & nd & nd & 17.0 \\
\hline 15.0 & nd & 31.0 & 30.0 & 40.0 & nd & 29.0 & nd & 40.0 & 31.0 & 38.0 & nd & nd & 32.0 \\
\hline 4.00 & nd & 6.00 & 4.94 & 2.90 & nd & 4.00 & nd & 2.90 & 3.00 & 2.70 & nd & nd & 3.00 \\
\hline 1.19 & nd & 2.14 & 1.94 & 2.21 & nd & 1.95 & nd & 1.83 & nd & nd & nd & nd & 1.96 \\
\hline 3.56 & nd & 3.26 & 10.90 & 5.40 & nd & 5.16 & nd & 3.94 & nd & nd & nd & nd & 3.58 \\
\hline 6.00 & nd & 7.30 & nd & 7.20 & nd & 6.80 & nd & 7.30 & nd & nd & nd & nd & 6.00 \\
\hline nd & nd & nd & 47.30 & 50.42 & nd & nd & nd & 53.49 & 55.68 & 50.74 & 68.15 & nd & 45.54 \\
\hline nd & nd & nd & 99.95 & 99.33 & nd & nd & nd & 107.36 & 118.03 & 99.50 & 138.60 & nd & 90.33 \\
\hline nd & nd & nd & 42.68 & 41.41 & nd & nd & nd & 45.77 & 43.84 & 41.85 & 53.37 & nd & 38.65 \\
\hline nd & nd & nd & 7.64 & 8.22 & nd & nd & nd & 9.06 & 9.07 & 8.20 & 10.09 & nd & 7.73 \\
\hline nd & nd & nd & 0.94 & 1.22 & nd & nd & nd & 1.20 & 1.38 & 1.23 & 1.74 & nd & 1.03 \\
\hline nd & nd & nd & 5.63 & 5.97 & nd & nd & nd & 6.80 & 5.98 & 5.67 & 6.61 & nd & 5.74 \\
\hline nd & nd & nd & 4.35 & 3.82 & nd & nd & nd & 4.88 & 4.06 & 4.15 & 4.38 & nd & 4.08 \\
\hline nd & nd & nd & 1.96 & 1.66 & nd & nd & nd & 2.00 & 2.02 & 1.75 & 2.16 & nd & 1.71 \\
\hline nd & nd & nd & 2.07 & 1.74 & nd & nd & nd & 1.93 & 2.13 & 1.83 & 2.17 & nd & 1.74 \\
\hline nd & nd & nd & 0.29 & 0.26 & nd & nd & nd & 0.31 & 0.32 & 0.25 & 0.32 & nd & 0.28 \\
\hline
\end{tabular}



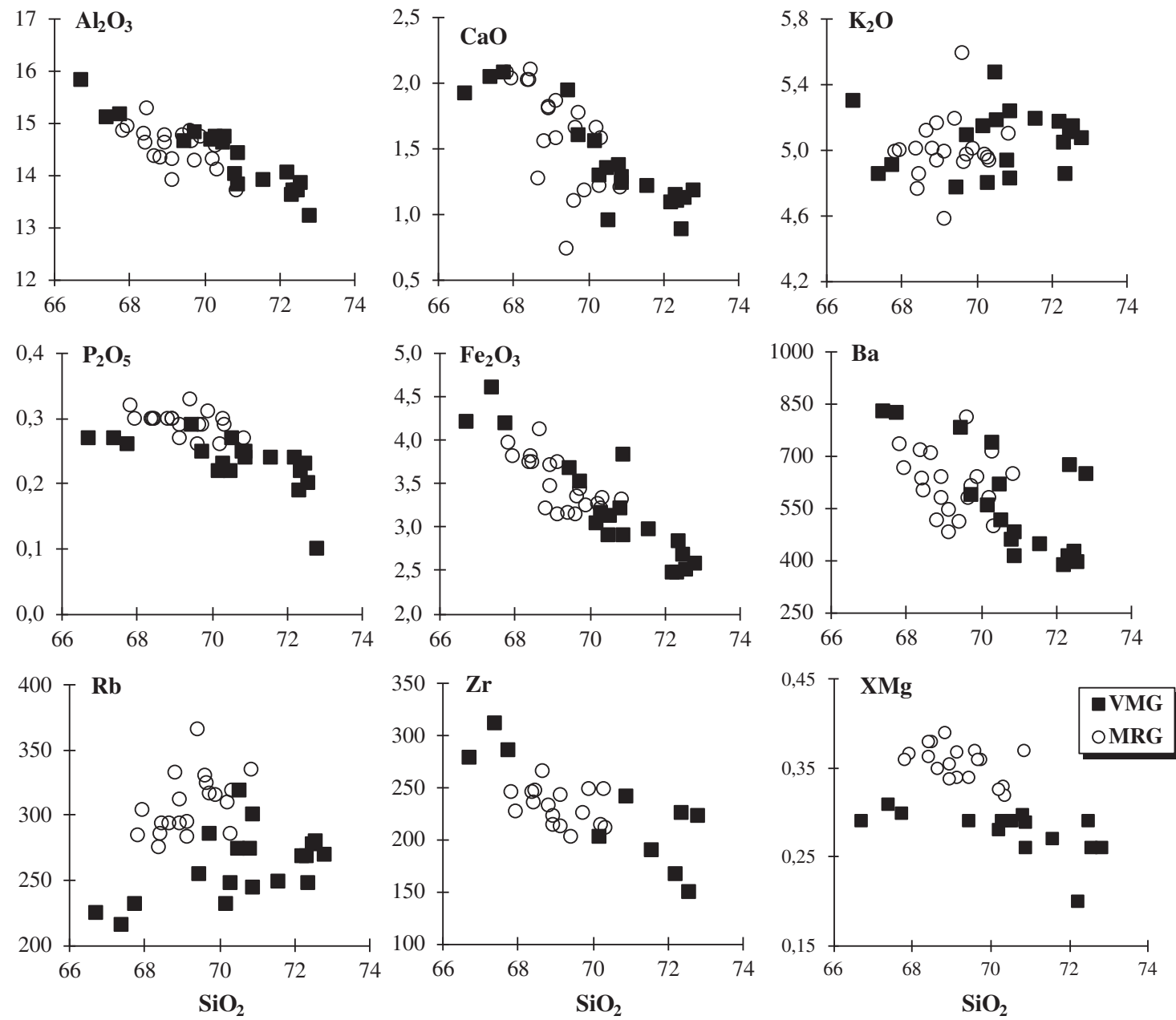

Fig. 6. Variation diagrams of selected major (wt.\%), trace (ppm) elements and XMg from the Vieira do Minho granite (VMG) and the Moreira de Rei granite (MRG),

Higher $\delta^{18} \mathrm{O}$ values in the VMG suggest that they could be derived for slightly shallower protoliths than the MRG (e.g. Holk and Taylor, 1997; Villaseca and Herreros, 2000).

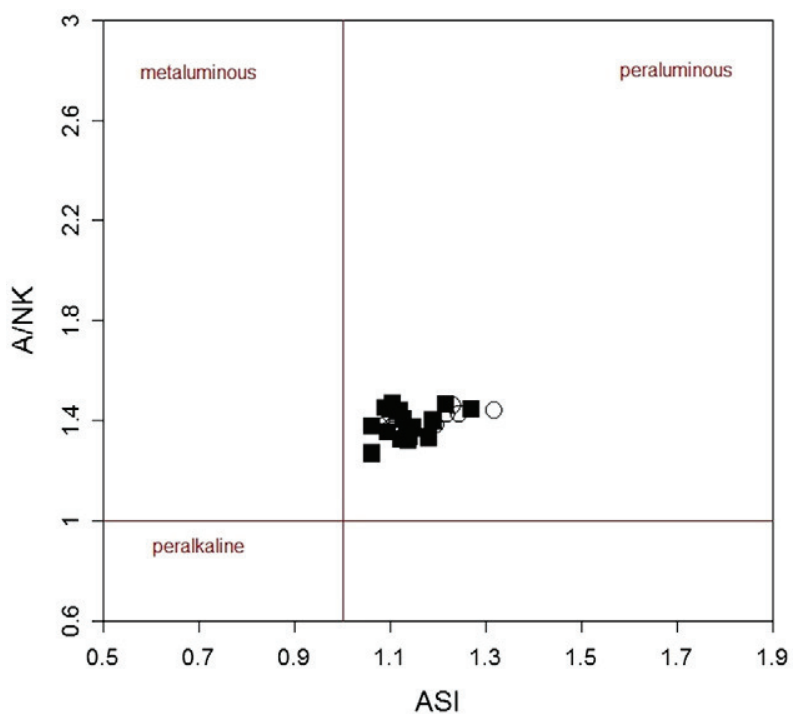

Fig. 7. A/NK versus ASI classification diagram (Frost et al., 2001) from the Vieira do Minho granite (VMG) and the Moreira de Rei granite (MRG). Symbols as in Fig. 6.

\section{Discussion}

\subsection{Structural constraints to granite emplacement}

Internal fabrics of granitoids are often regarded as representative strain markers to investigate crustal deformation (e.g. Turriollot et al., 2011). According to the magnetic susceptibility values, no magnetite is present and biotite appears as the main carrier of the magnetic susceptibility. This feature points out the paramagnetic behaviour of the granites of Vieira do Minho which allows to include this pluton in the "magnetite-free granites" group (Ishihara, 1977) as is usually found in Central Iberian Zone (Sant'Ovaia et al., 2011). Therefore, the magnetic fabrics measured within the granite during the AMS survey can be directly correlated to the magmatic fabrics of the main granite body. Within the pluton, the magnetic foliations are NW-SE striking, having steep dips to NE in the MRG and lower dips to $S W$ in the VMG. This pattern shows that in both granites, magnetic foliations dip to the geological limit of the two granites, parallel to the VRSZ, pointing out the role of this crustal anisotropy in the emplacement of both granites. The acquisition of this magnetic fabric can be the result of magma stretching parallel to magmatic flow, at the end of the last ductile Variscan deformation phase, D3. The magnetic fabric pattern records the evolution of regional tectonics during crystallization of the magma, which is also confirmed by the presence of high to medium temperature microstructures rather than only magmatic microstructures. In the case of both granites, the magmatic or high to medium temperature microstructures as well as the field data suggest that magma emplacement was late-tectonically driven. This 


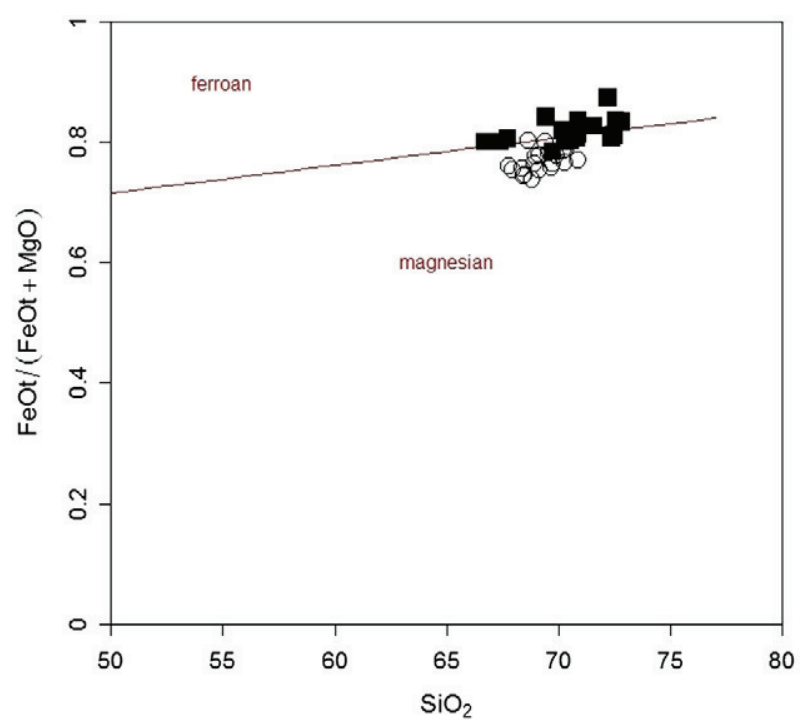

Fig. 8. $\mathrm{FeOt} /\left(\mathrm{FeOt}+\mathrm{MgO}\right.$ ) versus $\mathrm{SiO}_{2}$ classification diagram (Frost et al., 2001) from the Vieira do Minho granite (VMG) and the Moreira de Rei granite (MRG). Symbols as in Fig. 6.

assumption is corroborated by the values of $\mathrm{Km}$ and $\mathrm{P} \%$ parameters. According to Sant'Ovaia and Noronha (2005), Km higher than the $70 \times 10^{-6}$ SI and anisotropy between $2.5 \%$ and $4 \%$ is typically of the
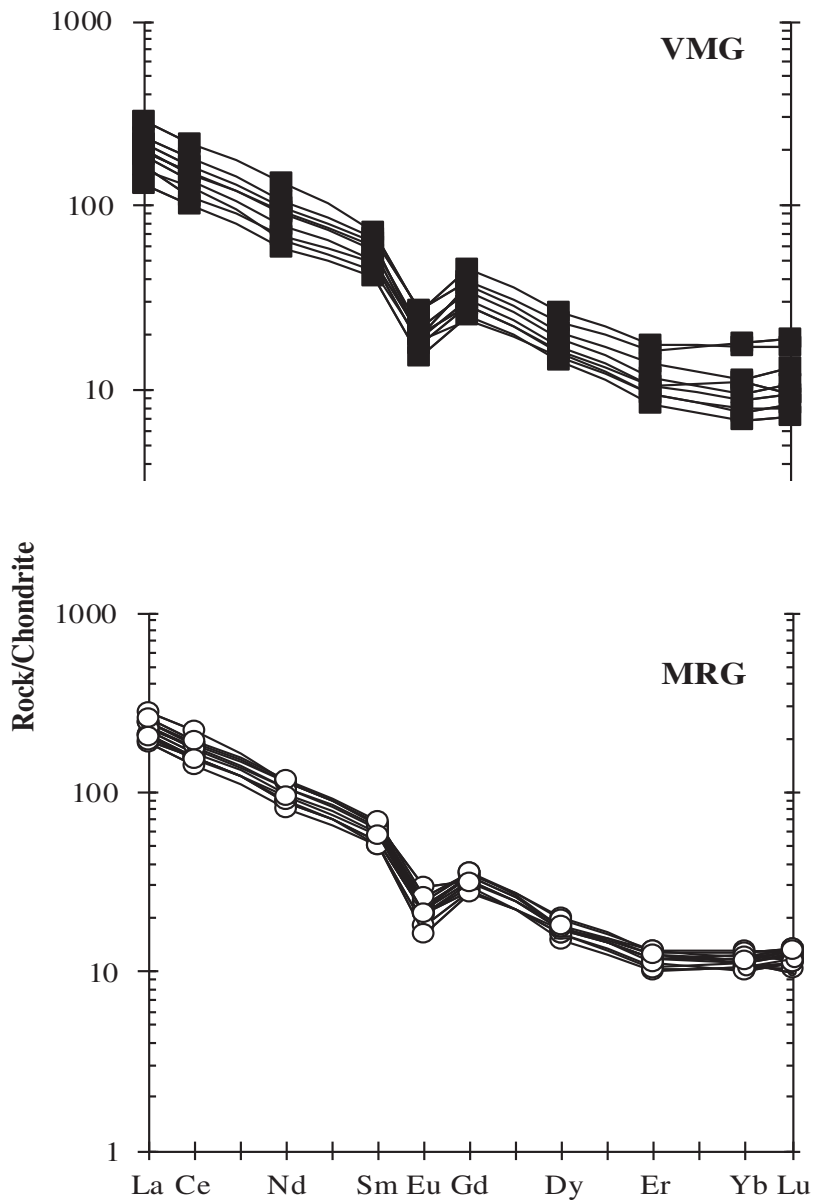

Fig. 9. Chondrite-normalized REE distribution patterns from the Vieira do Minho granite (VMG) and the Moreira de Rei granite (MRG). Normalization values are from Evensen et al. (1978).

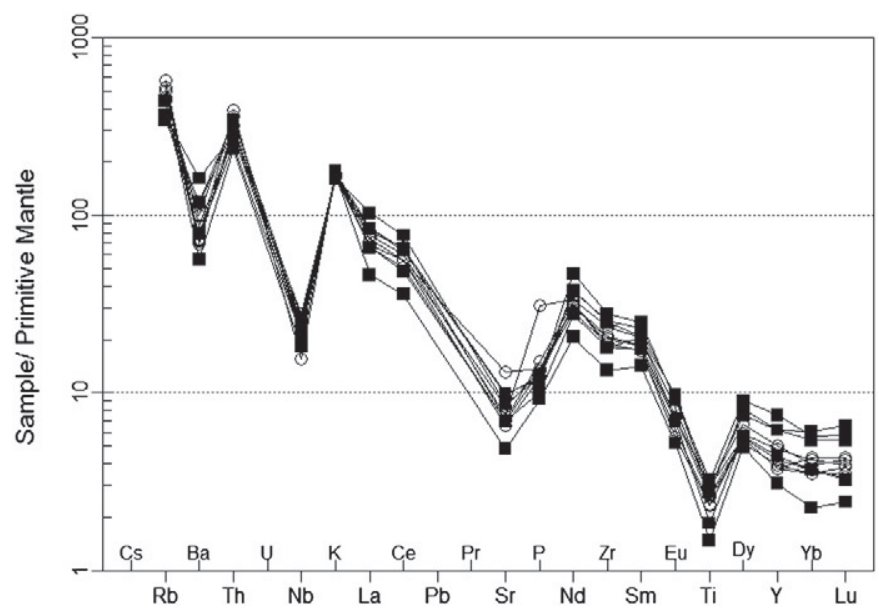

Fig. 10. Primitive-mantle normalized trace element multi-variation diagram from the Vieira do Minho granite (VMG) and the Moreira de Rei granite (MRG). Normalization values are from Sun and McDonough (1989). Symbols as in Fig. 9.

Variscan synorogenic biotite granites, where $\mathrm{P} \%$ corresponds to a weak orientation of the fabric.

We propose that the $\mathrm{D}_{3}$ Vigo-Régua transtensional shear zone and the structures related to it played an important role on the ascent of the granite magmas.

The U-Pb zircon and monazite data led us to consider that the $310 \pm 2 \mathrm{Ma}$ and the $307 \pm 3.5$ values are the age of emplacement and crystallisation of the VMG and the MRG, respectively. The narrow age range is in agreement with the geological data (late- $\mathrm{D}_{3} \mathrm{em}-$ placement) and suggest coeval emplacement of these two granites. These ages are consistent with published zircon $\mathrm{U}-\mathrm{Pb}$ ages on neighbouring granite plutons from northern Portugal (Dias et al., 2002, and references therein). They furthermore agree with ages, which have been reported from Aguado et al. (2005), Dias et al. (1998) and Fernández-Suárez et al. (2000) for late- $\mathrm{D}_{3}$ plutonism in the Cental Iberian Zone (306-311 Ma).

\subsection{Nature of the granite sources}

The protolith nature of Variscan granites in Central Iberian Zone is an ongoing subject of intense debate, and the complex geodynamic setting as well as the geochemical and isotopic variability make difficult to establish their potential sources. The lack of appropriate sources in terms of isotopic composition has led to consider several models for the origin of the peraluminous granites: (i) mixing or assimilation between crustal melts and mantle-derived magmas (Castro et al., 1999; Dias and Leterrier, 1994; Dias et al., 2002, 2009; Moreno-Ventas et al., 1995) (ii) partial melting of essentially crustal sources either from mid-crustal levels (Bea et al., 2003; Neiva, 1998) or from infracrustal materials, namely metaigneous rocks (Dias et al., 2002, 2009; Martins et al., 2009; Villaseca and Herreros, 2000; Villaseca et al., 1998, 1999).

Large granitoid batholiths of variable age and typology emplaced in the $\mathrm{CIZ}$, during the post-thickening extension of the Variscan orogeny, offers a good opportunity to constrain those questions. Available data set reveal that synorogenic granites (320-300 Ma) and post-orogenic granites (299-290 Ma) are characterised by contrasting magmatic affinities, as well as contrasting isotope compositions. Some of the synorogenic granites frequently occur in composite plutons, associated with coeval gabbro-norite to granodiorite bodies, in which is included the Vieira do Minho pluton. The VMG contains rare mafic microgranular enclaves and is spatially associated with $\mathrm{hm}$ - to $\mathrm{km}$-sized gabbroic to granodioritic bodies, south of the studied area. Both granitoids and basic-intermediate rocks show evidence of mixing/mingling phenomena 
Table 5

$\mathrm{Sr}, \mathrm{Nd}$ and $\delta^{18} \mathrm{O}$ isotopic data selected from the Vieira do Minho Granite (VMG) and the Moreira de Rei Granite (MRG).

\begin{tabular}{|c|c|c|c|c|c|c|c|c|c|c|c|c|}
\hline & $\mathrm{Rb}$ tot & Sr tot & ${ }^{87} \mathrm{Rb} /{ }^{86} \mathrm{Sr}$ & ${ }^{87} \mathrm{Sr} /{ }^{86} \mathrm{Sr}$ & ${ }^{87} \mathrm{Sr} /{ }^{86} \mathrm{Sr}_{\mathrm{i}}$ & $\mathrm{Nd}$ & $\mathrm{Sm}$ & ${ }^{147} \mathrm{Sm} /{ }^{144} \mathrm{Nd}$ & ${ }^{143} \mathrm{Nd} /{ }^{144} \mathrm{Nd}$ & $\varepsilon_{\mathrm{Nd}}$ & $\mathrm{T}_{\mathrm{DM}}$ & $\delta^{18} \mathrm{O}$ \\
\hline & $(\mathrm{ppm})$ & (ppm) & & $\pm(2 \sigma)$ & (310 Ma) & (ppm) & (ppm) & & $\pm(2 \sigma)$ & (310 Ma) & $(\mathrm{Ga})$ & $\%$ \\
\hline \multicolumn{13}{|l|}{ VMG } \\
\hline $6 C-30$ & 268 & 202 & 2.985 & $0,7417489(4)$ & 0.7286 & 33.78 & 6.54 & 0.1170 & 0.511959 (5) & -5.51 & 1.34 & 11.0 \\
\hline $6 C-32$ & 232 & 140 & 4.805 & $0.7310123(6)$ & 0.7098 & 36.27 & 6.92 & 0.1154 & $0.511977(6)$ & -5.15 & 1.29 & - \\
\hline $6 C-40$ & 254 & 247 & 2.979 & $0.721800(4)$ & 0.7087 & 52.27 & 9.53 & 0.1102 & $0.511972(5)$ & -5.24 & 1.26 & 10.6 \\
\hline $10 \mathrm{~A}-11^{\mathrm{a}}$ & 249 & 105 & 6.881 & $0.739082(20)$ & 0.7089 & 42.51 & 8.13 & 0.1156 & 0.512185 & -5.66 & 1.37 & - \\
\hline $10 \mathrm{~A}-23^{\mathrm{a}}$ & 261 & 119 & 6.364 & $0.736903(18)$ & 0.7090 & 33.27 & 6.67 & 0.1211 & $0.512198(9)$ & -5.62 & 1.37 & - \\
\hline \multicolumn{13}{|l|}{ MRG } \\
\hline $6 C-51$ & - & - & - & - & - & - & - & - & - & - & - & 10.5 \\
\hline $6 C-24$ & - & - & - & - & - & - & - & - & - & - & - & 9.9 \\
\hline B9.58 ${ }^{\mathrm{a}}$ & 261 & 233 & 3.251 & $0.720803(15)$ & 0.7066 & 52.17 & 8.69 & 0.1007 & $0.512190(8)$ & -4.98 & 1.32 & - \\
\hline PL9.109a & 317 & 171 & 5.362 & $0.729861(15)$ & 0.7064 & 40.02 & 7.01 & 0.1059 & $0.512192(8)$ & -5.15 & 1.33 & - \\
\hline PL9.130 & 305 & 152 & 5.805 & $0.732505(15)$ & 0.7071 & 39.97 & 7.55 & 0.1142 & $0.512173(9)$ & -5.84 & 1.39 & - \\
\hline ST9.77 ${ }^{\mathrm{a}}$ & 281 & 221 & 3.690 & $0.723129(10)$ & 0.7070 & 47.22 & 8.00 & 0.1031 & $0.512183(7)$ & -5.21 & 1.34 & - \\
\hline ST9.83 ${ }^{\mathrm{a}}$ & 304 & 202 & 4.361 & $0.726263(16)$ & 0.7072 & 45.49 & 7.70 & 0.1030 & $0.512148(6)$ & -5.89 & 1.39 & - \\
\hline ST9.118 & 278 & 205 & 3.929 & 0.724670 & 0.7075 & 45.79 & 7.77 & 0.1026 & $0.512144(9)$ & -5.96 & 1.39 & - \\
\hline
\end{tabular}

- Not determined.

a Data from Dias et al. (2002).

and a hybrid origin has been suggested (Dias et al., 2002, 2009). These authors propose that the gabbro-norite rocks, although having a primitive character, show $\mathrm{Sr}-\mathrm{Nd}$ isotope composition $\left(\mathrm{Sr}_{\mathrm{i}}=0.7049-0.7053\right.$, $\varepsilon_{\mathrm{Nd}}=-2.1$ to -2.5$)$ suggesting the existence of a sub-Iberian enriched mantle during the Variscan event. The enriched nature of subcontinental mantle domains is also present in other sectors within the Variscan Belt (Fernández-Suárez et al., 2011; Janousek et al., 2000; Moreno-Ventas et al., 1995; Orejana et al., 2009; Pin and Duthou, 1990; Villaseca et al., 2011).

Further constraints about the hybridisation process in the genesis of granitoids are given by the presence of mafic microgranular enclaves associated with granitic rocks, as they are generally considered as representing a mantle-derived component (Barbarin and Didier,

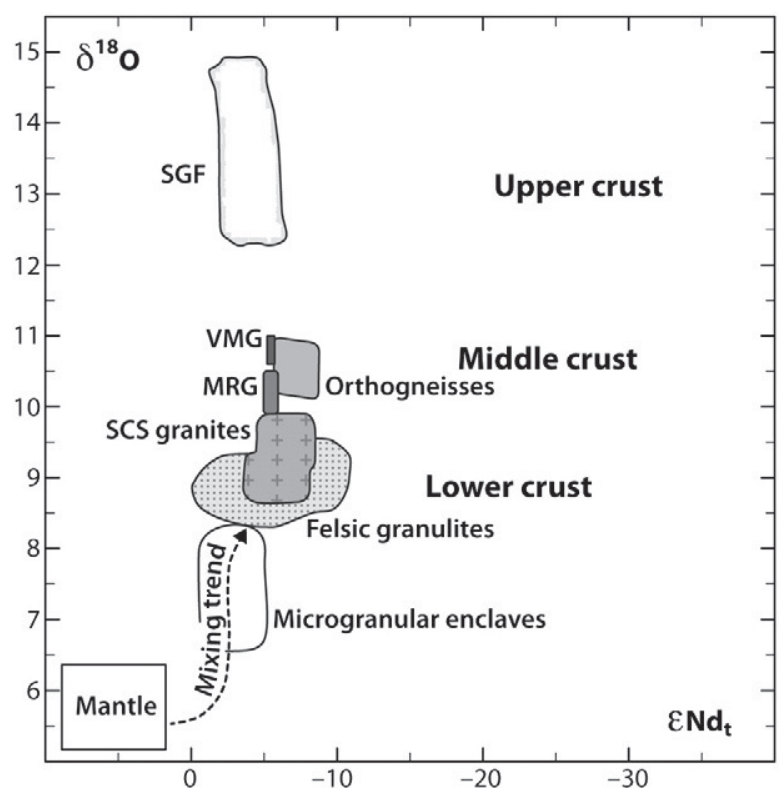

Fig. 11. Plot of initial $\varepsilon_{\mathrm{Nd}}$ vs. $\delta^{18} \mathrm{O}$ values for the Vieira do Minho granite (VMG) and the Moreira de Rei granite (MRG), Spanish Central System (SCS) Variscan granites and potential sources in the Variscan basement (Villaseca and Herreros, 2000, modified); Nd and oxygen isotopic data of SCS granites and orthogneisses are from Villaseca et al. (1998) and Villaseca and Herreros (2000); Nd and oxygen isotopic data of felsic granulites are from Villaseca et al. (1999) and Villaseca and Herreros (2000); data of Upper-Precambrian Schist-Greywacke Formation (SGF) of the Central Iberian Zone are from Ugidos et al. (1997); microgranular enclaves data are from Recio et al. (1992), Pinarelli and Rottura (1995) and Moreno-Ventas et al. (1995); other isotopic data are from Table 5 .
1992; Bea et al., 1999; Bonin, 2004; Cocherie et al., 1994; Collins et al., 2000; Dias and Leterrier, 1994; Dias et al., 2002; Didier, 1987; Janousek et al., 2004; Moreno-Ventas et al., 1995; Orsini et al., 1991; Renna et al., 2006; Silva and Neiva, 2004; Slaby and Martin, 2008; Vernon, 1984).

The MRG presents a lot of mafic microgranular enclaves, suggesting a significant mantle input and a more hybrid nature. According to Dias et al. (2002) the gabbro-norites represent the most likely source for the mantle-derived melt end-member in the genesis of the MRG, being the felsic member similar to the VMG crustal magma. Nevertheless, in Fig. 11 the mafic microgranular enclaves plot in an intermediate field between granites and mantle-derived magmas, suggesting chemicalinteraction between basic magmas and crustal melts. In addition, there is no isotopic indication for significant mantle contribution in the genesis of granites from the Vieira do Minho pluton. The involvement of such contribution requires a large volume of basic rocks, which is not present in the area. A minor involvement of coeval mafic magmas with the granitoids is enough to explain the presence of local intermingling and mafic microgranular enclaves in granitoids (e.g., Villaseca and Herreros, 2000). The proportions of gabbro-diorite: tonalite-granodiorite: granites are 1:11:88 contrasting with those found in continental margins, 16:58:26 (Castro et al., 2010; Pitcher, 1978) with scarce peraluminous series, suggesting that different sources and/or different melting or crystallization processes were involved in granite petrogenesis. Mechanisms other than pure crustal melting could generate peraluminous magmas (e.g. Barbarin, 1996)

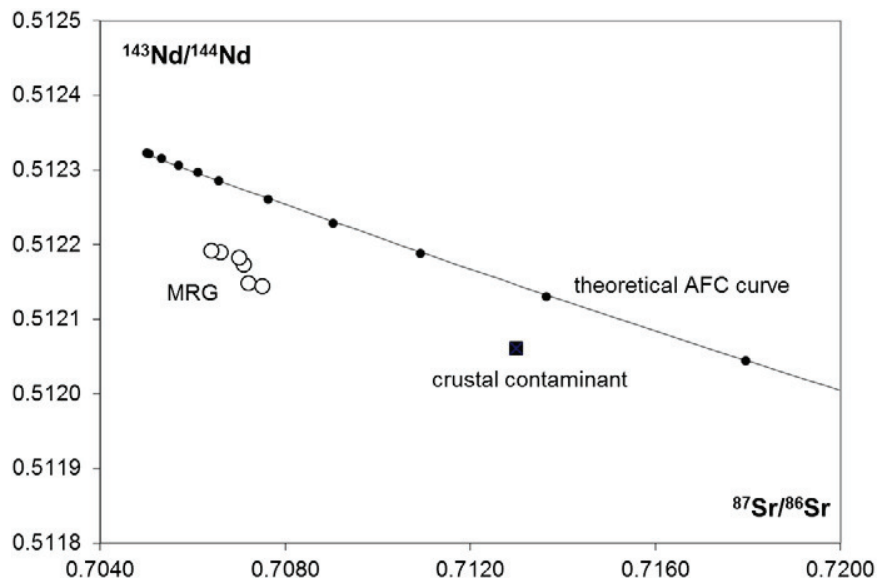

Fig. 12. $\left({ }^{143} \mathrm{Nd} /{ }^{144} \mathrm{Nd}\right)_{310 \mathrm{Ma}} \mathrm{vs}\left({ }^{87} \mathrm{Sr} /{ }^{86} \mathrm{Sr}\right)_{310 \mathrm{Ma}}$ showing the theoretical AFC curve (De Paolo, 1981) with $r=0.3$. 
but it seems unlikely that they could generate large batholiths of peraluminous felsic granites. Melting-assimilation experiments carried out by Castro et al. (1999) at $1000{ }^{\circ} \mathrm{C}$ and 4,7 and $10 \mathrm{kbar}$ and using a proportion of 50\% gabbro and 50\% gneiss give high silica-rich melt proportions (more than 50 vol.\%) whose compositions closely overlap those of the studied peraluminous monzogranites. Although, fractionation together with assimilation have frequently been observed in calc-alkaline magmatic complexes they cannot be invoked to explain the chemical and isotopic evolution of the granites from de Vieira do Minho pluton. An AFC model for several $r$ values was applied to these granites, assuming that the gabbro from Dias et al. (2002) and the VMG are a good approximation for the mantle-derived magma and the crustal contaminant, respectively. However the large spread of the samples away from the modelled theoretical curve is not consistent with this petrogenetic process (Fig. 12). According to Brophy (2009) fractionation mechanisms worked well in explaining differentiation in calc-alkaline systems where large volumes of mafic rocks are accompanied by only a small volume of highly evolved rocks, which is not the case. Furthermore U-Pb geochronological and petrological data from Variscan gabbros support the argument that these rocks are not mafic precursors of the associated granite magmatism, but mostly coeval (e.g. Orejana et al., 2009; Villaseca et al., 2011). All these arguments preclude the possibility that the studied peraluminous granites represent an evolved fraction from a more basic magma. Thus we see no evidence that the studied granites could represent the more evolved fractionates from a calc-alkaline system. The composition of these monzogranites is different from that of melts obtained experimentally from pelitic protoliths, rather suggesting a major involvement of metaigneous protoliths or metagreywacke sources (Conrad et al., 1988; Holtz, 1989; Holtz and Johannes, 1991; Johannes and Holtz, 1996; Patiño-Douce and Johnston, 1991).

The VMG shows mineralogical and geochemical features that are characteristic of crustal-derived magmas. It is a peraluminous monzogranite in which microgranular mafic enclaves are rare or absent. It presents a slightly more evolved chemical composition when compared with the MRG (more aluminous and less magnesian biotites) and more enriched $\mathrm{Sr}-\mathrm{Nd}$ isotopic signature $\left(\mathrm{Sr}_{\mathrm{i}}=0.7087-\right.$ $0.7098, \varepsilon_{\mathrm{Nd}}=-5.5$ to -5.2 ). The most suitable crustal source with an appropriate $\mathrm{Sr}-\mathrm{Nd}$ composition on the basement of the Iberian Massif is a felsic lower crust. In what concerns the composition of the lower crust in the Iberian Massif we have to emphasize the data about the deep structure of the crust in this sector obtained by deep seismic profiles undertaken by the Iberian Lithosphere Heterogeneity and Anisotropy Project (ILIHA DSS GROUP, 1993). The data showed a continental crust of around $30 \mathrm{~km}$ in thickness, similar to the average crustal thickness of Phanerozoic fold belts of Central Europe (Wedepohl, 1995). The lowermost $8 \mathrm{~km}$ correspond to a granulitic lower crust with P-wave velocities always in the range of 6.5-6.9 km/s, which are more typical of felsic compositions (Villaseca et al., 1999). According to Téllez et al. (1993) the structure of the crust in Northern Portugal is similar to that of Central Spain (Suriñach, 1988). Besides the ILIHA crustal data show that there are no significant lateral inhomogeneities in deep Iberian crustal structure in contrast to the heterogeneous Variscan surface geology. It has been suggested that the melt of this lower crust gives a peraluminous granite liquid in equilibrium with restitic material corresponding to metaigneous peraluminous felsic granulites (e.g. Orejana et al., 2011; Villaseca et al., 1999), which eventually formed some batholiths of the Central Iberian Zone. The initial Sr isotopic ratios in the range of $0.706-0.713$ and $\varepsilon_{\mathrm{Nd}}$ from -2 to -8 in these felsic metaigneous rocks (Villaseca et al., 1999) match to those of the VMG and the MRG monzogranites (Table 5). Moreover the outcropping metamorphic and metasedimentary rocks from low to middle and upper crust have a clearly different isotopic composition (Beetsma, 1995; Villaseca et al., 1998). Therefore we propose that the felsic granulites could be a potential source for the studied granites. Recent studies on U-Pb zircon ages in the Spanish Central System granulites seem to reinforce this conclusion, showing an abundant population of metamorphic zircons formed in the range 320-275 Ma (Orejana et al. 2012) which match the age of crystallisation of the analysed granites.

In Fig. 11 it is possible to observe that the $\delta^{18} \mathrm{O}$ values of the VMG (in the range of $10.6 \%$ to $11.0 \%$ ) also support a metaigneous source as outcropping orthogneisses have $\delta^{18} \mathrm{O}$ values in the range of 10.1 to $10.9 \%$ (Villaseca and Herreros, 2000). Oxygen isotopes results from lower crustal granulite xenoliths exhibit a lower range in $\delta^{18} \mathrm{O}$ values from 8.3 to 9.6\% (Villaseca and Herreros, 2000). Nevertheless, other felsic metaigneous granulites are slightly enriched in $\delta^{18} \mathrm{O}$ with an average $\delta^{18} \mathrm{O}$ values around $10 \%$ (Hoefs, 2009), which are more similar to those obtained for the studied granites. Higher $\delta^{18} O$ values are found in outcropping metamorphic wall rocks (e.g. Ugidos et al., 1997; Villaseca and Herreros, 2000), suggesting that values over $10 \%$ might involve shallower crustal protoliths. Thus, the VMG could be derived from shallower meta-igneous protolith than the MRG (Fig. 11).

Giving the above considerations, deduced from oxygen isotope mean values, the granites from the studied pluton were probably derived from metaigneous protoliths at different crustal levels. The available data, thus, suggest an extensive crustal recycling event at the post-collisional stage of the Variscan orogeny. However, we think that other kinds of data (such as Lu-Hf isotopes) would be necessary for a deeper discussion on the nature of the granites protolith.

\section{Conclusions}

Geochronological and geochemical data together with the microstructures and AMS results provided the following conclusions:

- The two granites that compose the Vieira do Minho pluton have similar values of $\mathrm{Km}, \mathrm{P} \%$ and $\mathrm{T}$. Km values indicate that the magnetic mineralogy is dominated by paramagnetic minerals such as biotite. Magnetic anisotropy is typically of the Variscan late-tectonic biotitic granites, where $\mathrm{P} \%$ corresponds to a weak orientation of the fabric. Shape parameter show oblate AMS ellipsoids that point out the contribution of the biotite to the AMS fabric. The regional consistency of magnetic fabric, NW-SE striking magnetic foliations associated to magnetic lineations with the same direction, and the NW-SE $\mathrm{D}_{3}$ regional structures, show that the acquisition of the fabric can be the result of magma stretching parallel to the magmatic flow, at the end of the last ductile Variscan deformation phase, $D_{3}$. This enhances the role of NW-SE structures on the granite magmas ascent and emplacement.

- The U-Pb zircon age obtained in the present study is consistent with field relationships and structural data and suggests a late-tectonic emplacement. The late-tectonic feature of the studied granites is also supported by high to medium temperature microstructures which suggests that the magma suffers significant deformation once crystallized.

The $\mathrm{U}-\mathrm{Pb}$ zircon and monazite data led us to consider that the $310 \pm 2 \mathrm{Ma}$ and the $307 \pm 3.5$ values are the age of emplacement and crystallisation of the VMG and the MRG, respectively. The narrow age is in agreement with the geological data (late- $\mathrm{D}_{3}$ emplacement) and suggests coeval emplacement of these two granites. These ages are consistent with published zircon U-Pb ages on similar granite plutons from northern Portugal, namely Celeirós, Braga and Celorico de Basto plutons (Dias et al., 2002, and references therein).

- The Vieira do Minho pluton results from the sub-contemporaneous ascent and emplacement of two distinct granite magma batches. The Vieira do Minho pluton consists of two peraluminous monzogranites, the VMG and the MRG. Both have similar $\varepsilon_{\mathrm{Nd}}$ values $(\mathrm{VMG}=-5.2$ to -5.7 ; $\mathrm{MRG}=-4.98$ to -5.96$)$ but the VMG is slightly enriched in ${ }^{87} \mathrm{Sr} /{ }^{86}{ }_{\mathrm{i}}=0.7087-0.7098$ as well as in $\delta^{18} \mathrm{O}$ in the range of $10.6 \%$ o to $11.0 \%$ o than the MRG with ${ }^{87} \mathrm{Sr} /{ }^{86}{ }_{i}=0.7064$ 
0.7075 and $\delta^{18} \mathrm{O}=9.9 \%$ \% $10.5 \%$. These granites are associated with coeval scarce gabbroic intrusions and/or mafic microgranular enclaves which are not considered as mafic precursors of the associated granitic magmatism. Instead, based on the available data set, metaigneous crustal protoliths, at different levels, are proposed. The interaction between the continental crust and invading mafic magmas could have been limited to mere heat transfer.

\section{Acknowledgments}

We are grateful to Carlos Villaseca for his corrections and suggestions to a previous version of our paper. The authors wish to thank J. Leterrier for his assistance at GRPG (Nancy-France) and for fruitful discussions. Gil Ibarguchi (País Vasco University, Spain) and Clemente Recio (Salamanca University, Spain) are thanked for their diligence in the performance of Sr-Nd and oxygen isotope analyses. L. Guillermo Corretgé, an anonymous reviewer and the editor G. Nelson Eby are thanked for their constructive and valuable reviews of this manuscript. This research was carried out at the Geology Center (Porto University), an R and D unit from Portuguese Foundation of Science and Technology.

\section{References}

Aguado, B.V., Azevedo, M.R., Schaltegger, U., Martinez Catalán, J.R., Nolan, J., 2005. U-Pb zircon and monazite geochronology of Variscan magmatism related to synconvergence extension in Central Northern Portugal. Lithos 82, 169-184.

Almeida, A., Martins, H.C.B., Noronha, F., 2002. Hercynian acid magmatism and related mineralisations in Northern Portugal. Gondwana Research 5 (2), 423-434.

Andrade, M., Noronha, F., 1981. Sobre a ocorrência de "vaugneritos" e de rochas gabróicas na região de Fafe. II Congresso Nacional de Geociências: Livro de resumos. Universidade de Coimbra.

Arzi, A.A., 1978. Critical phenomena in the rheology of partially-molten rocks. Tectonophysics 44, 173-184.

Barbarin, B., 1996. Genesis of the two main types of peraluminous granitoids. Geology 24, 295-298.

Barbarin, B., Didier, J., 1992. Genesis and evolution of mafic microgranular enclaves through various types of interaction between coexisting felsic and mafic magmas. Transactions of the Royal Society of Edinburgh: Earth Sciences 83, 145-153.

Bea, F., Montero, P., Molina, J.F., 1999. Mafic precursors, peraluminous granitoids, and late lamprophyres in the Avila batholith: a model for the generation of Variscan batholiths in Iberia. Journal of Geology 107 (4), 399-419.

Bea, F., Montero, P., Zinger, T., 2003. The nature, origin and thermal influence of the granite source layer of Central Iberia. Journal of Geology 111, 579-595.

Beetsma, J.J., 1995. The late Proterozoic/Paleozoic and Hercynian crustal evolution of the Iberian Massif, Northern Portugal, Ph.D. Thesis, Vrige Universiteit Amsterdam.

Benn, K., 1994. Overprinting of magnetic fabrics in granites by small strains: numerical modeling. Tectonophysics 233, 153-162.

Blumenfeld, P., Bouchez, J.L., 1988. Shear criteria in granite and migmatite deformed in the magmatic and solid states. Journal of Structural Geology 10, 361-372.

Bonin, B., 2004. Do coeval mafic and felsic magmas in post-collisional to within-plate regimes necessarily imply two contrasting, mantle and crustal, sources? A review. Lithos 78, 1-24.

Bouchez, J.L., 1997. Granite is never isotropic: an introduction to AMS studies of granitic rocks. In: Bouchez, J.L., Hutton, D.H.W., Stephens, W.E. (Eds.), Granite: From Segregation of Melt to Emplacement Fabrics. Kluwer Academic Publishers, Dordrecht.

Bouchez, J.L., Delas, C., Gleizes, G., Nedelec, A., Cuney, M., 1992. Submagmatic microfractures in granites. Geology 20, 35-38.

Brophy, J.G., 2009. Decompression and $\mathrm{H}_{2} \mathrm{O}$ exsolution driven crystallization and fractionation: development of a new model for low-pressure fractional crystallization in calc-alkaline magmatic systems. Contributions to Mineralogy and Petrology 157, 797-811.

Carignan, J., Hild, P., Mevelle, G., Morel, J., Yeghicheyan, D., 2001. Routine analyses of trace elements in geological samples using flow injection and low pressure online liquid chromatography coupled to ICP-MS; a study of geochemical reference materials BR, DR-N, UB-N, AN-G and GH. Geostandards Newsletter 25, 187-198.

Castro, A., Patiño-Douce, A., Corretgé, L.G., De La Rosa, J., El-Biad, M., El-Himid, H., 1999 Origin of peraluminous granites and granodiorites, Iberian Massif, Spain: an experimental test of granite petrogenesis. Contributions to Mineralogy and Petrology $135,255-276$

Castro, A., Gerya, T., García-Casco, A., Fernández, C., Díaz-Alvarado, J., Moreno-Ventas, I., Löw, I., 2010. Melting relations of MORB-sediment mélanges in underplated mantle wedge plumes; implications for the origin of Cordilleran-type batholiths. Journal of Petrology 51 (6), 1267-1295.

Cocherie, A., Rossi, Ph., Fouillac, A.M., Vidal, Ph., 1994. Crust and mantle contributions to granite genesis - an example from the Variscan batholith of Corsica, France, studied by trace-element and Nd-Sr-O-isotope systematics. Chemical Geology 115, 173-211.

Collins, W.J., Richards, S.R., Healy, B.E., Ellison, P.I., 2000. Origin of heterogeneous mafic enclaves by two-stage hybridisation in magma conduits (dykes) below and in granitic magma chambers. Transactions of the Royal Society of Edinburgh: Earth Sciences $91,27-45$

Conrad, W.K., Nicholls, I.A., Wall, V.J., 1988. Water-saturated and undersaturated melting of metaluminous and peraluminous crustal composition at $10 \mathrm{~kb}$ : evidence for the origin of silicic magmas in the Taupo Volcanic Zone, New Zealand, and other occurrences. Journal of Petrology 29, 765-803.

De Paolo, D.J., 1981. Trace element and isotopic effects of combined wall rock assimilation and fractional crystallization. Earth and Planetary Science Letters 52, 177-184.

Dias, G., Leterrier, J., 1994. The genesis of felsic-mafic plutonic associations: a Sr and Nd isotopic study of the Hercynian Braga Granitoid Massif (Northern Portugal). Lithos $32,207-223$.

Dias, R., Ribeiro, A., 1995. The Ibero-Armorican Arc: a collision effect against an irregular continent? Tectonophysics 246, 113-128.

Dias, G., Leterrier, J., Mendes, A., Simões, P.P., Bertrand, J.M., 1998. U-Pb zircon and monazite geochronology of post-collisional Hercynian granitoids from the Central Iberian Zone (Northern Portugal). Lithos 45, 349-369.

Dias, G., Simões, P.P., Ferreira, N., Leterrier, J., 2002. Mantle and crustal sources in the genesis of late-Hercynian granitoids (NW Portugal): geochemical and Sr-Nd isotopic constraints. Gondwana Research 5 (2), 287-305.

Dias, D., Noronha, F., Simões, P.P., Almeida, A., Martins, H.C.B., Ferreira, N., 2009. Geochronology and petrogenesis of late-Variscan plutonism (NW Portugal): Synthesis and inferences on crustal recycling and growth. Geochimica et Cosmochimica Acta 73 (13), A288.

Didier, J., 1987. Contribution of enclave studies to the understanding of origin and evolution of granitic magmas. Geologische Rundschau 76, 41-50.

Evensen, N.M., Hamilton, P.J., O'Nion, R.K., 1978. Rare-earth abundances in chondritic meteorites. Geochimica et Cosmochimica Acta 42, 1199-1212.

Fernández-Suárez, J., Dunning, G.R., Jenner, G.A., Gutiérrez-Alonso, G., 2000. Variscan collisional magmatism and deformation in NW Iberia: constraints from U-Pb geochronology of granitoids. Journal of the Geological Society London 157, 565-576.

Fernández-Suárez, J., Gutierrez-Alonso, G., Johnston, S.T., Jeffries, T.E., Pastor-Galan, D., Jenner, G.A., Murphy, J.B., 2011. Iberian late-Variscan granitoids: some considerations on crustal sources and the significance of "mantle extraction ages". Lithos $123(1-4), 121-132$.

Ferreira, N., Iglésias, M., Noronha, F., Pereira, E., Ribeiro, A., Ribeiro, M.L., 1987. Granitóides da Zona Centro Ibérica e seu enquadramento geodinâmico. In: Bea, F., Carnicero, A., Gonzalo, J., Lopez Plaza, M., Rodriguez Alonso, M. (Eds.), Geologia de los Granitoides y Rocas Asociadas del Macizo Hesperico. Editorial Rueda, Libro de Homenaje a L.C. García de Figuerola, Madrid, pp. 37-51.

Frost, B.R., Barnes, C.G., Collins, W.J., Arculus, R.J., Ellis, D.J., Frost, C.D., 2001. A geochemical classification for granitic rocks. Journal of Petrology 42 (11), 2033-2048.

Gébelin, A., Martelet, Chen, Y., Brunel, M., Faure, M., 2006. Structure of late Variscan Millevaches leucogranite massif in the French Massif Central: AMS and gravity modelling results. Journal of Structural Geology 28 (1), 148-169.

Gleizes, G., Leblanc, D., Bouchez, J.L., 1997. Variscan granites of the Pyrenees revisited: their role as syntectonic markers of the orogen. Terra Nova 9, 38-41.

Hoefs, J., 2009. Stable Isotopic Geochemistry, 6th ed. Spriger Verlag, Germany (288 pp.).

Holk, G.J., Taylor, H.P., 1997. 018/016 homogenization of the middle crust during anatexis: the Thor-Odin metamorphic core complex, British Columbia. Geology 25, 31-34.

Holtz, F., 1989. Importance of melt fraction and source rock composition in crustal genesis - the example of two granitic suites of northern Portugal. Lithos 24, 21-35.

Holtz, F., Johannes, W., 1991. Genesis of peraluminous granites I. Experimental investigation of melt compositions at 3 and $5 \mathrm{~kb}$ and various $\mathrm{H}_{2} \mathrm{O}$ activities. Journal of Petrology 32, 935-958.

Iglesias, M., Ribeiro, A., 1981. Zones de cisaillement ductile dans l'arc Ibero-Armorican. Comunicações dos Serviços Geológicos de Portugal 67, 85-87.

ILIHA DSS GROUP, 1993. A deep seismic sounding investigation of lithospheric heterogeneity and anisotropy beneath the Iberian Peninsula. Tectonophysics 221, 35-51.

Ishihara, S., 1977. The magnetite-series and ilmenite-series granitic rocks. Mining Geology 27, 292-305.

Jacobsen, S.B., Wasserburg, G.J., 1984. Sm-Nd isotopic evolution of chondrites and achondrites, II. Earth and Planetary Science Letters 67, 137-150.

Janousek, V., Bowes, D.R., Rogers, G., Farrrow, C.M., Jelínek, E., 2000. Modeling diverse processes in the petrogenesis of a composite batholith: the Central Bohemian Pluton, Central European Hercynides. Journal of Petrology 41, 511-543.

Janousek, V., Braithwaite, C.J.R., Bowes, D.R., Gerdes, A., 2004. Magma-mixing in the genesis of Hercynian calc-alkaline granitoids: an integrated petrographic and geochemical study of the Sázava intrusion, Central Bohemian Pluton, Czech Republic. Lithos 78, 67-99.

Jelinek, V., 1981. Characterization of the magnetic fabric of rocks. Tectonophysics 79, 63-67.

Johannes, W., Holtz, F., 1996. Petrogenesis and experimental petrology of granitic rocks. Springer-Verlag, Berlim (335 pp.).

Julivert, M., Fontboté, J.M., Ribeiro, A., Conde, L., 1974. Mapa tectónico de la Península Ibérica y Baleares, escala 1:1 000 000. Instituto. Geologico y Mineiro, España, 113 pp.

Krogh, T.E., 1973. A low-contamination method for hydrothermal decomposition of zircon and extraction of $\mathrm{U}$ and $\mathrm{Pb}$ for isotopic age determination. Geochimica et Cosmochimica Acta 48, 505-511.

Krogh, T.E., 1982. Improved accuracy of U-Pb zircon ages by the creation of more concordant systems using an air abrasion technique. Geochimica et Cosmochimica Acta 46, 637-649.

Lagarde, J.L., Capdevila, R., Fourcade, S., 1992. Granites et collision continentale: l'exemple des granitoides carboniferes dans la chaine hercynienne ouesteuropéenne. Bulletin de la Société Géologique 163 (5), 597-610.

Ludwig, K.R., 2003. Isoplot 3.00: A Geochronological Toolkit for Microsoft Excel. Special Publication n²4Berkeley Geochronology Center (74 pp.). 
Martins, H.C.B., Noronha, F., 2000a. Sources of late-Hercynian biotite-rich granite plutons from Northern Portugal: inferences from zircon morphology. Cadernos Laboratorio Xeolóxico de Laxe 25, 257-260.

Martins, H.C.B., Noronha, F., 2000b. Composição e natureza das biotites dos maciços graníticos tardi-hercínicos de Vieira do Minho e Vila Pouca de Aguiar (N de Portugal). Comunicações do Instituto Geológico e Mineiro 87, 35-52.

Martins, H.C.B., Sant'Ovaia, H., Noronha, F., 2009. Genesis and emplacement of felsic Variscan plutons within a deep crustal lineation, the Penacova-Régua-Verín fault: an integrated geophysics and geochemical study (NW Iberian Peninsula). Lithos 111 (3-4), 142-155.

Martins, H.C.B., Sant'Ovaia, H., Abreu, J., Oliveira, M., Noronha, F., 2011. Emplacement of the Lavadores granite (NW Portugal): U/Pb and AMS results. Comptes Rendus Geoscience 343 (6), 387-396.

Mendes, A.C., Dias, G., 2004. Mantle-like Sr-Nd isotope composition of Fe-K subalkaline granites: the Peneda-Gerês Variscan massif (NW Iberian Peninsula). Terra Nova 16, 109-115.

Moreno-Ventas, I., Rogers, G., Castro, A., 1995. The role of hybridization in the genesis of Hercynian granitoids in the Gredos Massif, Spain: inferences from Sr-Nd isotopes. Contributions to Mineralogy and Petrology 120, 137-149.

Neiva, A.M.R., 1998. Geochemistry of highly peraluminous granites and their minerals between Douro and Tamega valleys, northern Portugal. Chemical Erde 58, 161-184.

Nicolas, A., 1992. Kinematics in magmatic rocks with special reference to gabbros. Journal of Petrology 33, 891-915.

Noronha, F., Lima, J., 1992. Carta geológica de Portugal à escala de 1:50 000. 6C (Cabeceiras de Basto). Serviços Geológicos de Portugal, Lisboa.

Noronha, F., Ramos, J.M.F., Rebelo, J.A., Ribeiro, A., Ribeiro, M.L., 1979. Essai de corrélation des phases de déformation hercynienne dans le Nord-Ouest Péninsulaire. Boletim da Sociedade Geológica de Portugal 21, 227-237.

Orejana, D., Villaseca, C. Pérez-Soba, C., López-Garcia, J.A., Billström, K., 2009. The Variscan gabros from the Spanish Central System: a case for crustal recycling in the sub-continental lithospheric mantle? Lithos 110, 262-276

Orejana, D., Villaseca, C., Armstrong, R.A., Jeffries, T.E., 2011. Geochronology and trace element chemistry of zircon and garnet from granulite xenoliths: constraint on the tectonothermal evolution of the lower crust under central Spain Lithos 124, 103-116.

Orejana, D., Villaseca, C., Valverde-Vaquero, P., Belousova, E.A., Armstrong, R.A., 2012. U$\mathrm{Pb}$ geochronology and zircon composition of late Variscan S- and I-type granitoids from the Spanish Central System batholith. International Journal of Earth Sciences $101,1789-1815$.

Orsini, J.B., Cocirta, C., Zorpi, M.J., 1991. Genesis of mafic microgranular enclaves through differentiation of basic magmas, mingling and chemical exchanges with their host granitoid magmas. In: Didier, J., Barbarin, B. (Eds.), Enclaves and Granite Petrology: Developments in Petrology, 13. Elsevier, Amsterdam.

Parrish, R.R., 1987. An improved micro-capsule for zircon dissolution in U-Pb geochronology. Chemical Geology 66, 99-102.

Paterson, S.R., Vernon, R.H., Tobisch, O.T., 1989. A review of criteria for the identification of magmatic and tectonic foliations in granitoids. Journal of Structural Geology $11,349-363$

Patiño-Douce, A.E. 1999. What do experiments tell us about the relative contributions of crust and mantle to the origin of granitic magmas? In: Castro, A., Férnandez, C., Vigneresse, J.L. (Eds.), Understanding granites: integrating new and classical techniques: Geological Society London, 168, pp. 55-75.

Patiño-Douce, A.E., Johnston, A.D., 1991. Phase equilibria and melt productivity in the politic system: implications for the origin of peraluminous granitoids and aluminous granulites. Contributions to Mineralogy and Petrology 107, 202-218.

Pin, C., Bassin, C., 1992. Evaluation of a strontium-specific extraction chromatographic method for isotopic analysis in geological materials. Analytica Chimica Acta 269, 249-255.

Pin, C., Duthou, J.L., 1990. Sources of Hercynian granitoids from the French Massif Central: inferences from Nd-isotopes and consequences for crustal evolution. Chemical Geology $83,281-296$.

Pin, C., Santos Zalduegui, J.F., 1997. Sequential separation of light rare earth elements, thorium and uranium by miniaturized extraction chromatography: application to isotopic analyses of silicate rocks. Analytica Chimica Acta 339, 79-89.

Pin, C., Briot, D., Bassin, C., Poitrasson, F., 1994. Concomitant separation of strontium and samarium-neodymium for isotopic analyses in silicate samples, based on specific extraction chromatography. Analytica Chimica Acta 298, 209-217.

Pinarelli, L., Rottura, A., 1995. S rand Nd isotopic study and Rb-Sr geochronology of the Béjar granites, Iberian Massif, Spain. European Journal of Mineralogy 7, 577-589.

Pitcher, W.S., 1978. The anatomy of a batholith. Journal of the Geological Society of London $135,157-182$

Pupin, J.P., 1980. Zircon and granite petrology. Contributions to Mineralogy and Petrology $110,463-472$

Ramos, J.M.F., Santos Oliveira, J.M., Simões, M.C., 1981. Prospecção geológica e geoquímica na área de Cabeceiras de Basto. Memórias e Notícias 91/92, 89-111.

Recio, C., Fallick, A.E., Ugidos, J.M., 1992. A stable isotope $\left(\delta^{18} \mathrm{O}, \delta \mathrm{D}\right)$ study of the lateHercynian granites and their host-rocks in the Central Iberian Massif (Spain). Transactions of the Royal Society of Edinburgh: Earth Sciences 83, 247-257.

Renna, M.R., Tribuzio, R., Tiepolo, M., 2006. Interaction between basic and acid magmas during the latest stages of the post-collisional Variscan evolution: clues from the gabbro-granite association of Ota (Corsica-Sardinia batholith). Lithos 90, 92-110.

Ribeiro, A., 1974. Contribuition à l'étude tectonique de Trás-os-Montes Oriental. Comunicações dos Serviços Geológicos de Portugal 24, 1-168.
Ribeiro, A., Iglesias, M, Ribeiro, M.L, Pereira, E, 1983. Modéle géodynamique des Hercynides Ibériques. Comunicações dos Serviços Geológicos de Portugal 64, 191-214. Ribeiro, M. A., Martins, H. C. B., Almeida, A., Noronha, F., 2001. Notícia explicativa da Folha 6C-Cabeceiras de Basto. Carta Geológica de Portugal na escala 1/50 000 Departamento de Geologia Instituto Geológico e Mineiro. Lisboa, 48pp.

Rochette, P., 1987. Magnetic susceptibility of the rock matrix related to magnetic fabric studies. Journal of Structural Geology 9 (8), 1015-1020.

Rochette, P., Jackson, M., Aubourg, C., 1992. Rock magnetism and the interpretation of anisotropy of magnetic susceptibility. Reviews of Geophysics 30, 209-226.

Sant'Ovaia, H., Noronha, F., 2005. Classificação de granitos hercínicos com base nas suas características petrofisicas. Cadernos Laboratorio Xeolóxico de Laxe 30, 87-98.

Sant'Ovaia, H., Martins, H.C.B., Noronha, F., 2011. Anisotropy of Magnetic Susceptibility in Portuguese Variscan granites. Abstracts of the Seventh Hutton Symposium on Granites and related rocks. Avila, Spain, p. 130 (July 4-9).

Silva, M.M.V., Neiva, A.M., 2004. Geochemistry of high-Mg-K microgranular enclaves and host granites from Vila Nova de Gaia, Northern Potugal. Geochimica et Cosmochimica Acta 68 (11), A 658.

Slaby, E., Martin, E., 2008. Mafic and felsic magma interaction in granites: the Hercynian Karkonosze Pluton (Sudetes, Bohemian Massif). Journal of Petrology 49, 353-391.

Stacey. J.S. Kramers, J.D. 1975. Approximation of terrestrial lead isotope evolution by a two-stage model. Earth and Planetary Science Letters 26, 207-221.

Steiger, R.H., Jäger, E., 1977. Subcomission on geochronology: convention in the use of decay constants in geo- and cosmochronology. Earth and Planetary Science Letters 36, 359-362.

Sun, S.S., McDonough, W.F., 1989. Chemical and isotopic systematics of oceanic basalts: implications for mantle composition and processes. In: Saunder, A.D., Norry, M.J. (Eds.), Magmatism in the ocean basins: Geology Society Special Publication, 42, pp. 313-345.

Suriñach, E., 1988. Crustal structure in central Spain. In: Banda, E. Mendes Victor, LA (Eds.), Procedings 5th Workshop on the European Geotraverse (EGT), the Iberian Peninsula. European Science Foundation, Strasbourg, pp. 187-197.

Teixeira, C., Gonçalves, F., 1980. Introdução à Geologia de Portugal. Instituto Nacional de Investigação Científica, Lisboa (475 pp.)

Téllez, J., Matias, L.M., Córdoba, D., Mendes Victor, L.A., 1993. Structure of the crust in the schistose domain of Galicia-Tras-os-Montes (NW Iberian Peninsula). Tectonophysics 221, 81-93.

Thirlwall, M.F., 1991. Long-term reproductivility of multicollector Sr and Nd isotope ratio analysis. Chemical Geology 94, 85-104.

Turriollot, P., Faure, M., Martelet, G., Chen, Y., Augier, R., 2011. Pluton-dyke rlationships in a Variscan granitic complex from AMS and gravity modeling. Inception of the extensional tectonics in the South Armorican Domain (France). Journal of Structural Geology $33,1681-1698$.

Ugidos, J.M., Valladares, M.I., Recio, C. Rogers, G, Fallick, A.E, Stephens, W.E, 1997. Provenance of Upper Precambrian-Lower Cambrian shales in the Central Iberian Zone Spain: evidence from a chemical and isotopic study. Chemical Geology 136, 55-70.

Veloso, M.L., Dias, G., 1995. Estudo químico-mineralógico de encraves microgranulares máficos associados a granitoides tardi-hercínicos da região de Braga-Vieira do Minho (Norte de Portugal): tipo e mecanismos de hibridação. Memórias, Pulicações do Museu e laboratório de Mineralogia e Geologia da Universidade do Porto, 4, pp. 843-847.

Vernon, R.H., 1984. Microgranitoid enclaves in granites: globules of hybrid magma quenched in a plutonic environment. Nature 309, 438-439.

Vernon, R.H., 2000. Review of microstructural evidence of magmatic and solid-state flow. Electronic Geosciences 5 (2).

Vigneresse, J.L., Barbey, P., Cuney, M., 1996. Rheological transitions during partial melting and crystallization with application to felsic magma segregation and transfer. Journa of Petrology 37 (6), 1579-1600.

Villaseca, C., Herreros, V., 2000. A sustained felsic magmatic system: the Hercynian granitic batholith of the Spanish Central System. Transactions of the Royal Society of Edinburgh: Earth Sciences 91, 207-219.

Villaseca, C., Barbero, L., Rogers, G., 1998. Crustal origin of Hercynian peraluminous granitic batholits of central Spain: petrological, geochemical and isotopic ( $\mathrm{Sr}-\mathrm{Nd}$ ) arguments. Lithos 43, 55-79.

Villaseca, C., Downes, H., Pin, C., Barbero, L., 1999. Nature and composition of the lowe continental crust in central Spain and the granulite-granite linkage: inferences from granulitic xenoliths. Journal of Petrology 40 (1), 465-496.

Villaseca, C., Pérez-Soba, C. Merino, E Orejana, D., López-Garcia, J A Billstrom, K., 2008. Contrasting crustal sources for peraluminous granites of the segmented Montes de Toledo Batholith (Iberian Variscan Belt). Journal of Geosciences 53, 263-280

Villaseca, C., Bellido, C., Pérez-Soba, C., Billstrom, K., 2009. Multiple crustal sources for post-tectonic I-types granites in the Hercynian Iberian Belt. Mineralogy and Petrology 96, 197-211.

Villaseca, C., Orejana, D., Belousova, E., Armstrong, R.A., Pérez-Soba, C., Jeffries, T.E. 2011. U-Pb isotopic ages and Hf isotope compositions of zircons in Variscan gabbros from central Spain: evidence of variable crustal contamination. Mineralogy and Petrology 101, 151-167.

Wasserburg, G.J., Jacobsen, S.B., DePaolo, D.J., McCulloch, M.T, Wen, T., 1981. Precise determination of $\mathrm{Sm} / \mathrm{Nd}$ ratios, $\mathrm{Sm}$ and $\mathrm{Nd}$ isotopic abundances in standard solutions. Geochimica et Cosmochimica Acta 45, 2311-2323.

Wedepohl, K.H., 1995. The composition of the continental crust. Geochimica et Cosmochimica Acta 59, 1217-1232. 